\title{
Histological Study on the Effect of Hyaluronic Acid Injection (Dermal Filler) on the Skin of the Adult and Aged Albino Rat
}

\author{
Original \\ Article \\ Marian Gamal Magdy Aziz Aramanious, Elham Gamal El Din, \\ Soheir Kamal Ahmed, Mohamed Abd El Rahman Ahmed Mekway
}

Department of Histology and Cell Biology, Faculty of Medicine, Ain Shams University.

\begin{abstract}
Background: Injectable dermal fillers became more popular for improving skin contour defects such as wrinkles, lines, and depressed acne scars.

Aim of the work: This work aimed to study different skin changes induced by dermal filler injection in adult and aged albino rat.

Material and Methods: Forty five female albino rats were used. The animals were divided into three groups: Group I (Control): Included twenty adult rats. Group II: Included fifteen adult rats, they received an injection of $0.1 \mathrm{ml}$ of hyaluronic acid (HA). The animals were subdivided into three subgroups according to time of sacrification, five rats each: Subgroup IIa: after 7 days. Subgroup IIb: after 60 days. Subgroup IIc: after 90 days. Group III: Included ten aged rats, they were subdivided into two subgroups, five rats each: Subgroup IIIa: (Control aged group). Subgroup IIIb: the rats were given an injection of HA and were sacrificed after 30 days.

Results: Thin skin of HA injected animals revealed significant $(<0.05)$ increase in the thickness of subcutaneous tissue (SC) and significant increase in collagen and elastic fibers, and significant increase in the CD34 positive endothelial cells as compared to control and aged rats. Active fibroblasts at the site of injection showing euchromatic nuclei. Their cytoplasm contained well developed rER, numerous mitochondria, many vesicles, and centrioles.

Conclusion: Hyaluronic acid filler injection stimulated vascularization and enhanced fibroblasts to synthesize collgen and elastic fibers in SC. This protected the skin from aging features in adults,and play a role in improvement of skin defects in aged rats.
\end{abstract}

Received: 07 December 2018, Accepted: 06 January 2019

Key Words: CD34, dermal filler, hyaluronic acid, rats, senile skin.

Corresponding Author: Marian Gamal Magdy Aziz Aramanious, MD, Department of Histology and Cell Biology, Faculty of Medicine, Ain Shams University, Cairo, Egypt, Tel.: +20 1280810479, E-mail: popopary5@gmail.com

ISSN: 1110-0559, Vol. 42, No. 2

\section{INTRODUCTION}

A youthful face is characterized by smoothness, balance, fullness, and absence of facial wrinkles or lines. One of the most visible signs of skin alterations in aging process is facial wrinkles. The majority of approaches intending to reverse signs of skin-aging target the treatment of wrinkles. As aging continues, the subcutaneous fat pads shrink, leading to loss of the structural support which in turn creates sagging of the overlying skin. Loss of the facial volume beneath the skin (e.g. subcutaneous fat, muscle) was considered to be the major contributor to the appearance of advanced age ${ }^{[1]}$.

Dermal fillers are widely used for skin rejuvenation. Due to their efficacy and safety, HA based fillers had become a "gold" standard and the commonest type of fillers currently used. These fillers started to be utilized for three dimensional volumization, compensating for age-associated volume loss. Restoration of extracellular scaffold, stimulating formation of younger components of the skin by injectable cross-linked HA, provided a possible explanation of the mechanism of skin rejuvenation. Skin boosting was considered a new indication for clinical use of injectable cross-linked HA gels ${ }^{[2]}$. The fillers were found to be beneficial for various age demographics including young adults for enhancement of youthful features, middleaged adults for early prevention and volume restoration, and older individuals for delay and maintenance of agerelated symptoms ${ }^{[3]}$.

The dermal fillers were used as a non-surgical procedure to correct deficient or aesthetically detracting facial features. Historically, these fillers consisted of autologous fat, silicone, poly-tetrafluoroethylene, polymethylmethacralate, calcium hydroxyapatite, polylactic acid, or hydrogel ${ }^{[4]}$.

In recent years, injectable dermal fillers have challenged the use of invasive surgical procedures. Based on a survey conducted by the International Society of Aesthetic Plastic Surgery, there were more than eleven million non-surgical procedures performed worldwide in 2013, and more than three million involved resorbable fillers. Non-permanent dermal fillers were used for filling of rhytides and folds, and correction of soft-tissue loss caused by disease or age. 
These non-permanent fillers provided volume restoration, with minimal downtime, favorable safety profile, and rapid and reproducible results. According to the statistics of the American Society for Aesthetic Plastic Surgery, more than 1.6 million HA filler procedures were performed in 2014 in the United States, making it the second most frequently used nonsurgical esthetic procedure after botulinum $\operatorname{toxin}^{[5]}$.

\section{MATERIAL AND METHODS}

\section{Animals}

Forty five female albino rats were used in this study. The animals included thirty five adult rats (6-8 months) of average weight 150-200 grams and ten aged rats (one year) of average weight 250-300 grams. All animals were purchased and maintained in Medical Research Center, Ain Shams University with free access to water and standard rat chow for the period of experiment. They were housed in plastic cages with mesh wired covers.

\section{Products}

DERMAFILL - is a monophasic fourth generation injectable filler based on hyaluronic acid of non-animal origin and biodegradable. It was purchased from (SBSMED, France)

\section{Animal groups}

\section{The rats were divided into three main groups}

Group I (Control): Included twenty adult rats, five rats served as a negative control (received nothing). Fifteen rats were injected subcutaneously with equivalent volumes of normal saline. They were classified into three equal subgroups and sacrificed at the corresponding time with the rats of subgroups IIa, IIb and IIc.

Group II: Included fifteen adult rats. They received a single subcutaneous injection of $0.1 \mathrm{ml} \mathrm{HA}^{[6]}$ at right flank region. The animals were subdivided into three subgroups, five rats each:

- $\quad$ Subgroup IIa: the animals were sacrificed after 7 days.

- Subgroup IIb: the rats were sacrificed after 60 days.

- $\quad$ Subgroup IIc: they were sacrificed after 90 days.

Group III: Included ten aged rats. They were further subdivided into two subgroups, five rats each:

Subgroup IIIa: the rats received a single subcutaneous injection of equivalent volume of normal saline at right flank region. They were sacrificed after 30 days.

Subgroup IIIb: the rats were given a single subcutaneous injection of HA as in group II. They were sacrificed after 30 days.

\section{Preparation of tissues}

At the end of the experiment, all rats in each group were anaesthetized by intravenous injection of thiopental sodium in a dose $57.8 \mathrm{mg} / \mathrm{kg}$ (lethal dose $)^{[7]}$. Skin areas about two $\mathrm{cm} 2$ were obtained from a fixed part from right flank region, and divided into small pieces. The pieces were washed with distilled water to remove debris. Then the skin was processed for light and electron microscope examination.

\section{Histological and immunohistochemical studies}

Paraffin sections of $5 \mu \mathrm{m}$ thick were obtained and stained with Hematoxylin and Eosin to show the histological structures ${ }^{[8]}$ and Masson's trichrome stain ${ }^{[8]}$ to detect collagen fibers. Verhoeff-Van Gieson Stain was used to detect elastic fibers ${ }^{[9]}$. Immuno histochemical staining was also used for detection of transmembrane protein CD34class II of endothelial cells ${ }^{[10]}$.

\section{Transmission Electron Microscopical (TEM) study ${ }^{[8]}$}

Small pieces of thin skin were rapidly fixed and then processed for transmission electron microscopic study (TEM). Specimens were examined and photographed with JEOL- 1010 Transmission electron microscope, made in Japan, at EM unit at the Regional Center of Mycology and Biotechnology, Al-Azhar University, Cairo, Egypt.

\section{Morphometric and Statistical study}

The total thickness of the epidermis, dermis and the subcutaneous tissue was measured by using the LEICA Q win Image Analyzer. Area percentages of collagen fibers, elastic fibers as well as the area occupied by CD34 class II transmembrane protein of endothelial cells of blood vessels were also measured in the subcutaneous tissue. All these parameters were measured in 5 fields per slide. Five slides were used for each animal. The mean parameters for each animal were calculated.

ANOVA-one-way analysis was used to compare these parameters. Statistical analysis was performed with the SPSS computer program (version 20). Differences were considered significant when the $P$ value was $<0.05$ and non-significant when the $P$ value was $>0.05$. Values were expressed as mean $\pm \mathrm{SD}$.

\section{RESULTS}

\section{I-Histological results \\ 1.H\&E-stained sections}

Examination of H\&E stained sections of thin skin of adult albino rats of control group revealed that the skin was formed of epidermis, dermis and subcutaneous tissue (Fig. 1a). The epidermis was composed of stratified squamous keratinized epithelium. The keratinocytes were arranged in four layers, stratum basale, stratum spinosum, stratum granulosum and stratum corneum (Fig.1b). The dermis was composed of an outer papillary layer and an inner reticular layer. It appeared to contain hair follicles, sebaceous glands and collagen fibers. The subcutaneous tissue, under the dermis was formed of superficial layer of adipose tissue, deep layer of loose connective tissue and band of muscle fibers inbetween(Fig.1a). 
The skin of rats of subgroup IIa (scarified 7 days after HA injection), showed that the epidermis and dermis were comparable to the control group. An apparent increase in the thickness of subcutaneous tissue was noticed (Fig. 2a). Homogenous basophilic areas of fluid accumulation indicating the site of HA injection with few thin collagen fibrils inbetween (Fig. 2b).

More obvious increase in the thickness of subcutaneous tissue and collagen fibers around homogenous basophilic areas the of injected HA was also noticed in rats of subgroup IIb (animals scarified 60 days after HA). Numerous blood capillaries were also detected in the subcutaneous tissue of the skin of these rats (Figs .3a and 3b).

The skin of animals which were scarified 90 days after HA injection (subgroup IIc) showed that the two layers of the dermis, papillary and reticular layers contained thick, closely packed collagen fibers. The subcutaneous tissue showed obvious increase in thickness . fluid spaces and (Fig.4a). Numerous blood vessels of different sizes were also detected at the subcutaneous tissue. Noticed also abscence of fluid spaces and decrease in thickness of subcutaneous tissue compared with previous group IIa and IIb (Fig.4b).

Thin skin of rats of subgroup IIIa (control aged group rats), showed focal areas of discontinuation and disorganization of the epidermal cells were observed (Fig. 5a). The epidermal cells appeared distorted. Diorganized collagen and hair follicles and loss of collagen fibers in the dermis were detected (Fig.5b). Focal areas of mononuclear cellular infiltration were also seen in the dermis (Fig.5c). Disorganized epidermis with focal loss of cells with apparent reduction of the epidermal thickness were detected .Wide empty spaces were also noticed between the distorted collagen fibers in the dermis (Fig .5d).

Examination of the skin of senile rats, injected with HA and sacrificed after 30 days, revealed that the epidermis and dermis were nearly similar to the picture seen in the control adult rats. An apparent increase in the thickness of the subcutaneous tissue was obvious in comparison with that of rats of subgroup IIIa (Fig.6a). The epidermis appeared to be formed of the four usual layers, stratum basale, stratum spinosum, stratum granulosum and stratum corneum (Fig.6b).

\section{Masson's trichrome-stained sections}

Masson trichrome stained sections of the control group revealed that the papillary dermis contained fine interlacing collagen fibers just below the epidermis. Deeper dense and thick wavy collagen bundles appeared in the reticular dermis. The subcutaneous tissue contained fine collagen fibers and thin sheets of skeletal muscle fibers (Fig.7). An apparent increase in collagen fibers of subcutaneous layer was seen in rats of subgroup IIa, (animals sacrificed 7 days after HA) (Fig .8). More obvious increase in collagen fibers in the dermis as well as in the subcutaneous layer was also detected in the skin of rats of subgroup IIb which sacrificed 60 days after HA injection (Fig .9). Closely packed thick collagen fibers forming a continuous layer in the subcutaneous tissue were noticed in animals that received HA and sacrificed after 90 days (Fig .10).

The skin of control aged rats (Subgroup IIIa), showed disorganization of these collagen fibers in both papillary and reticular layers of the dermis with spaces of collagen fibers loss inbetween were seen (Fig .11). Whereas, in aged rats which were injected with HA and sacrificed after 30 days, (Subgroup IIIb) closely packed collagen fibers were observed in the dermis (Fig .12).

\section{Verhoeff Van-Gieason -stained sections}

Examination of these sections of control rats showed short branched thin elastic fibers in the subcutaneous region of the skin of the control rats (Fig.13). Long branched parallel elastic fibers were detected in the subcutaneous region at the site of injection in rats of both subgroups IIa and IIb (Figs.14 and 15) which were sacrificed after 7 days and 60 days respectively. Whereas, branched elastic fibers were seen in the subcutaneous region of rats of subgroup IIc (Fig .16).

The subcutaneous tissue of the control aged rats (subgroup IIIa) showed few faint elastic fibers in the dermis and hardly detected in the S.C tissue. Empty spaces were also observed between these fibres (Fig. 17). Whereas, the subcutaneous tissue of the senile rats injected with HA (subgroup IIIb) showed branched elastic fibers in their subcutaneous region (Fig .18).

\section{II- Immunohistochemical results}

Immunohistochemical staining for CD34 in control rats revealed faint positive reaction for $\mathrm{CD} 34$ in the endothelium of blood capillaries of the subcutaneous tissue (Fig. 19). An apparent increase in the positive reaction for CD34 was detected in the endothelium of blood capillaries of rats of subgroups IIa (Fig .20) as well as in rats of subgroup IIb (Fig .21).

Strong extensive brownish positive reaction for CD34 antibody in the endothelium of blood vessels of rats of subgroup IIc (Fig .22).

The endothelium of blood capillaries of the control senile group (subgroup IIIa) showed faint reaction for CD34 (Fig .23). An apparent increase in the positive immune reaction for CD34 antibody was seen in the endothelium of the numerous blood vessels of senile rats injected with HA (subgroup IIIb) (Fig .24).

\section{III-Electron microscopic results:}

Electron microscopic examination of dermis and subcutaneous tissue of rat's thin skin sections from the control group showed inactive fibroblasts with elongated nucleus and few organelles in the cytoplasm. Regularly arranged collagen fibers surrounding the fibroblasts were also seen (Fig. 25). In rats of subgroup IIa, the cytoplasm 
of the immature fibroblasts appeared to contain numerous mitochondria, many vesicles, well developed rough endoplasmic reticulum and two centrioles. Collagen fibers were regularly arranged in bundles. They showed the characteristic axial periodicity (Figs.26). Examination of the skin of rats of both subgroups IIb and IIc revealed that the active fibroblasts appeared with euchromatic nuclei. Their cytoplasm showed numerous dilated cisternae of well-developed rough endoplasmic reticulum which contained homogenous material of synthesized protein. The collagen fibers were regularly arranged surrounding the fibroblasts. The fibers appeared with their characteristic axial periodicity (Figs.27 and 28). Notcied that active fibroblast was compressed by fluid accumulation (Fig.28).

Examination of the skin of aged control rats (subgroup IIIa) revealed that some connective tissue inactive fibroblasts showed small shrunken nuclei with irregular nuclear membrane and small cytoplasm. Abnormal chromatin distribution of their nuclei was also detected. Their cytoplasmic organelles could be hardly identified. Few widely disperesed irregularly arranged collagen fibers were also observed (Fig .29). Connective tissue of this group showed also inflammatory cells (Fig .30). In rats of subgroup IIIb (senile rats sacrificed 30 days after HA injection), the fibroblasts in the dermis were surrounded by the regularly arranged collagen fibers. The nuclei of the active fibroblasts appeared with irregular nuclear membrane. Numerous mitochondria and rough endoplasmic reticulum were detected in their cytoplasm. Filopodia were extended from the cell surface to the nearby collagen fibers (Fig .31).

\section{IV-Morphometric and Statistical Results}

\section{The total thickness of the epidermis and dermis}

Non-significant changes were detected in the total epidermal and dermal thickness in rats of subgroups IIa, IIb, IIc and subgroup IIIb as compared to that of control group $(P>0.05)$. A significant reduction was observed in senile rats of subgroup IIIa when compared to that of control rats (group I) $(p<0.05)$. A significant increase was seen in rats of the subgroup IIIb $(p<0.05)$ when compared to that of senile animals of subgroup IIIa (Table 1 and Histograms 1 and 2).

\section{The total thickness of the subcutaneous tissue}

A significant increase in the total thickness of the subcutaneous tissue was observed in animals of subgroup IIa, IIb, IIc in comparison to that of the control group (group I) $(p<0.05)$. The highest peak of the total thickness was detected in rats of subgroup IIa. A significant increase in was observed in animals of subgroup IIIb when compared to that of senile animals of subgroup IIIa $(p<0.05)$ (Table 1 and Histogram 3).

\section{Area percentage of collagen fibers}

A significant increase in the area percentage of the collagen fibers was detected in rats of subgroup IIa,
IIb, IIc in comparison to that of the control animals (group I) $(p<0.05)$. A significant reduction was also noticed in senile rats of subgroup IIIa when compared to that of the control animals (group I) $(p<0.05)$. A significant increase was detected in rats of subgroup IIIb in comparison to that of the animals of subgroup IIIa $(p<0.05)$ (Table 1 and Histogram 4).

\section{Area percentage of elastic fibers}

A significant increase in the area percentage of elastic fibers was detected in rats of subgroup IIa, IIb, IIc in comparison to that of the control animals (groupI) $(p<0.05)$. A significant reduction was also noticed in senile rats of subgroup IIIa when compared to that of the control animals (group I) $(p<0.05)$. A significant increase was detected in rats of subgroup IIIb in comparison to that of the control animals (group I) $(p<0.05$ ) (Table 1 and Histogram 5).

\section{Area percentage of CD34}

A significant increase in the area percentage occupied by CD34 was detected in rats of subgroup IIa, IIb, IIc in comparison to that of the control animals (group I) $(p<0.05)$. A significant reduction was also noticed in senile rats of subgroup IIIa when compared to that of the control animals (group I) $(p<0.05)$. A significant increase was detected in rats of subgroup IIIb in comparison to that of the control animals (group I) $(p<0.05)$ (Table 1 and Histogram 6).

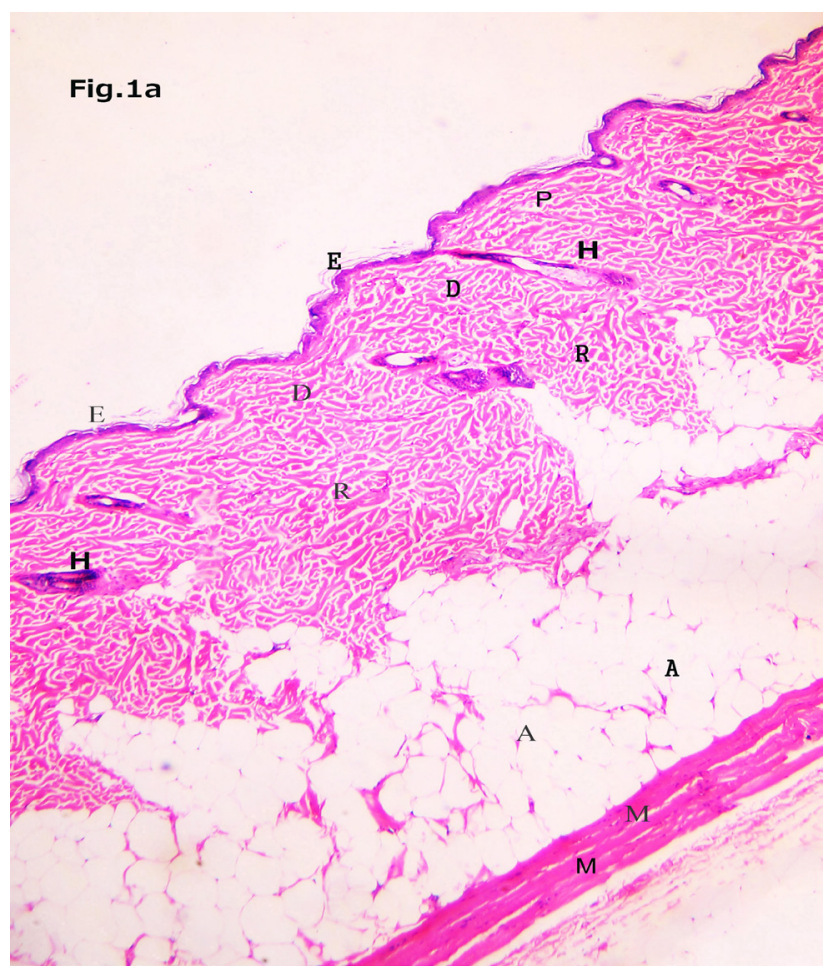

Fig.1a: A photomicrograph of a section in rat's thin skin of group I showing the two layers of the skin, the epidermis (E) and the dermis (D). The dermis shows an outer papillary layer $(\mathrm{P})$, an inner reticular layer $(\mathrm{R})$ and hair follicles(H).The subcutaneous tissue contains superficial layer of adipose tissue (A),deep layer of loose connective tissue and band of muscle fibers (M) in between. (Control group I H\&E x 40) 


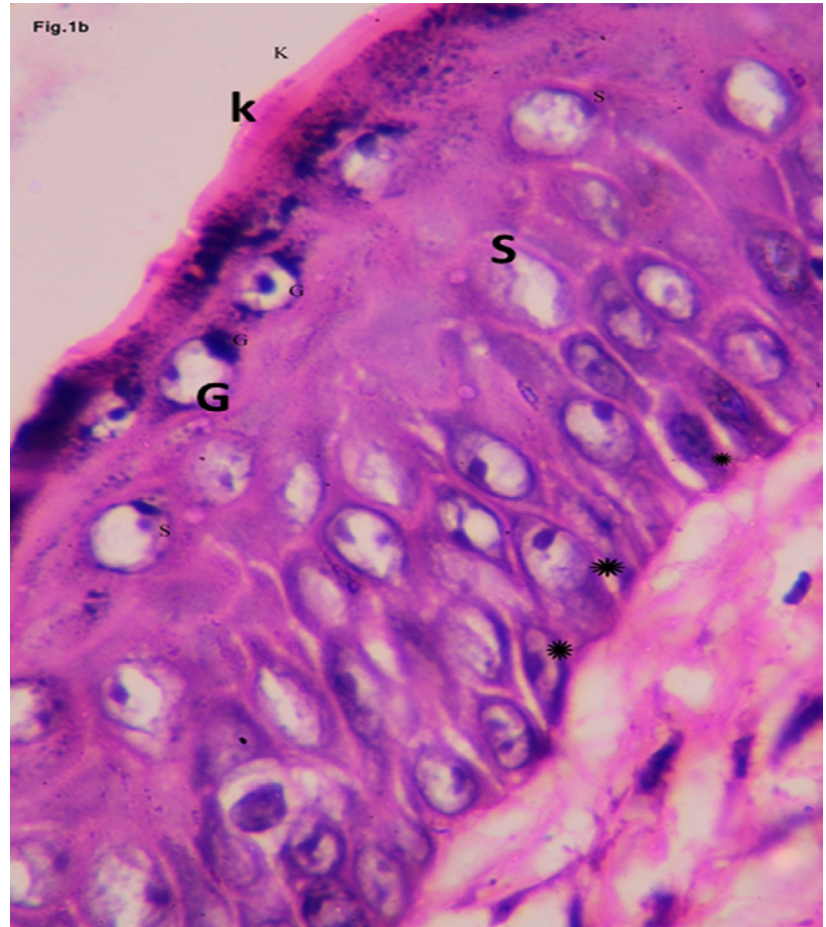

Fig.1b: Higher magnification showing the layers of the epidermis and part of papillary layer. The stratum basale $(*)$ is one cell layer of columnar cells rests on basement membrane. The stratum spinosum consists of many layers of polyhedral acidophilic cells with central rounded nuclei (S). The stratum granulosum cells are flattened with basophilic keratohylin granules in their cytoplasm (G). The stratum corneum consists of many layers of flattened non-cellular acidophilic keratin scales (K). (Control group I H\&E x 1000)

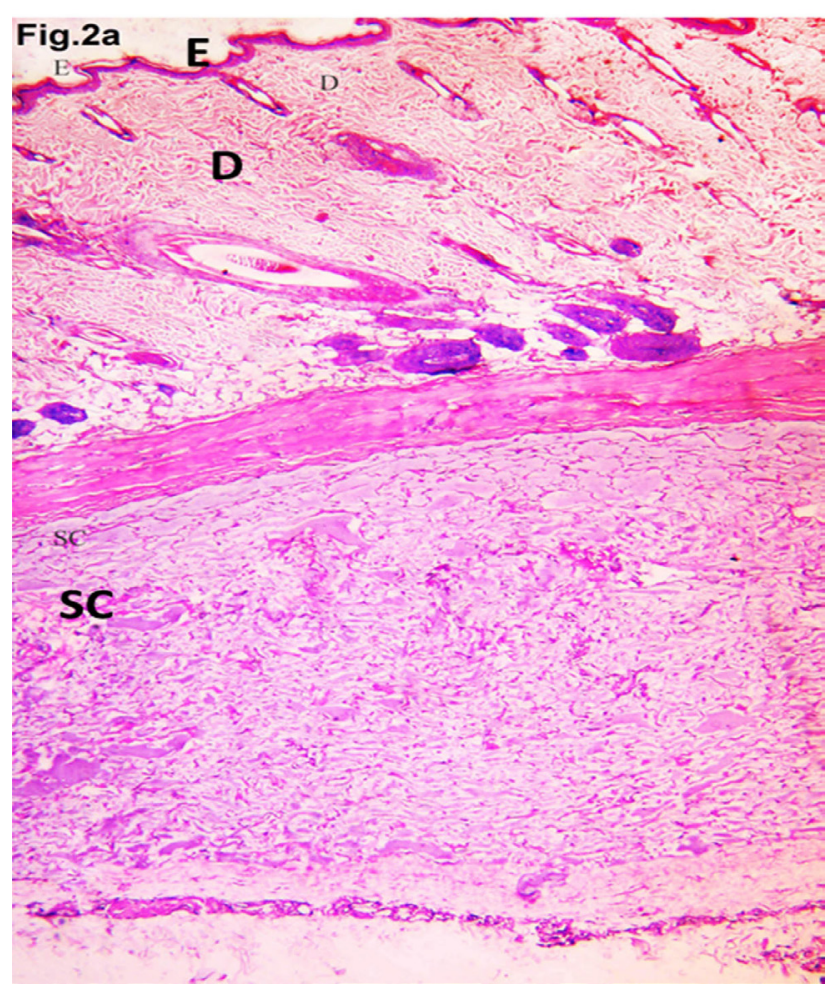

Fig.2a: A photomicrograph of a section in rat's thin skin of subgroup IIa showing the epidermis (E), dermis (D) and the subcutaneous (SC) tissue. An apparent increase in the thickness of subcutaneous tissue is obvious. (Subgroup IIa: H\&E x 40)

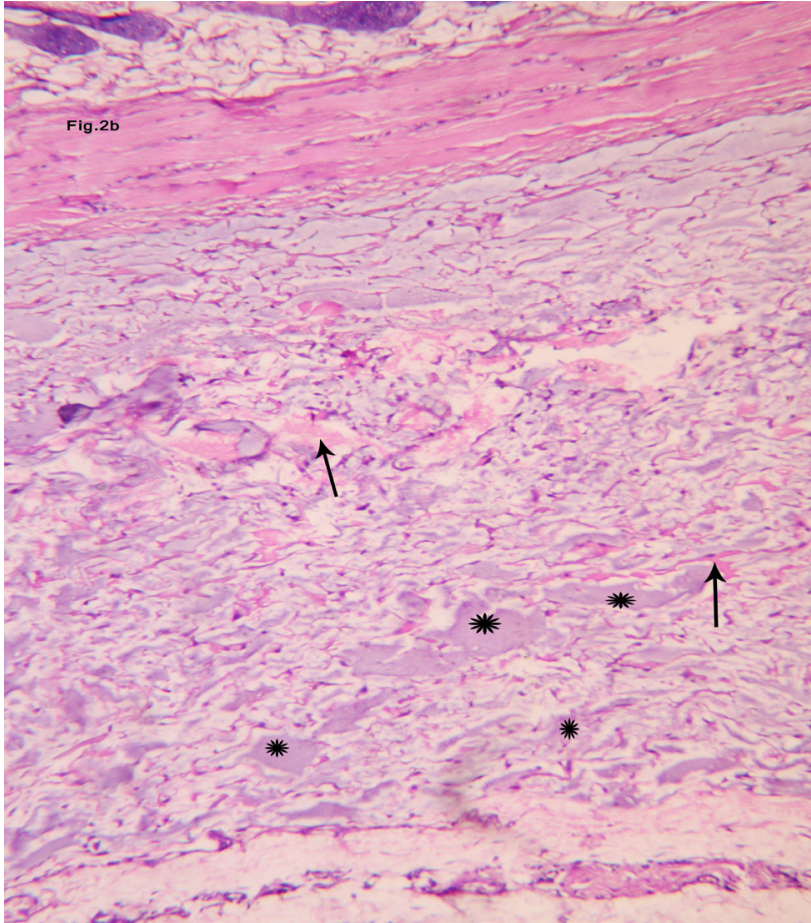

Fig.2b: Higher magnification of the previous section showing subcutaneous tissue with few thin collagen fibrils ( $\uparrow$ ) inbetween basophilic areas (*)of fluid accumulation. (Subgroup IIa: H\&E x 400)

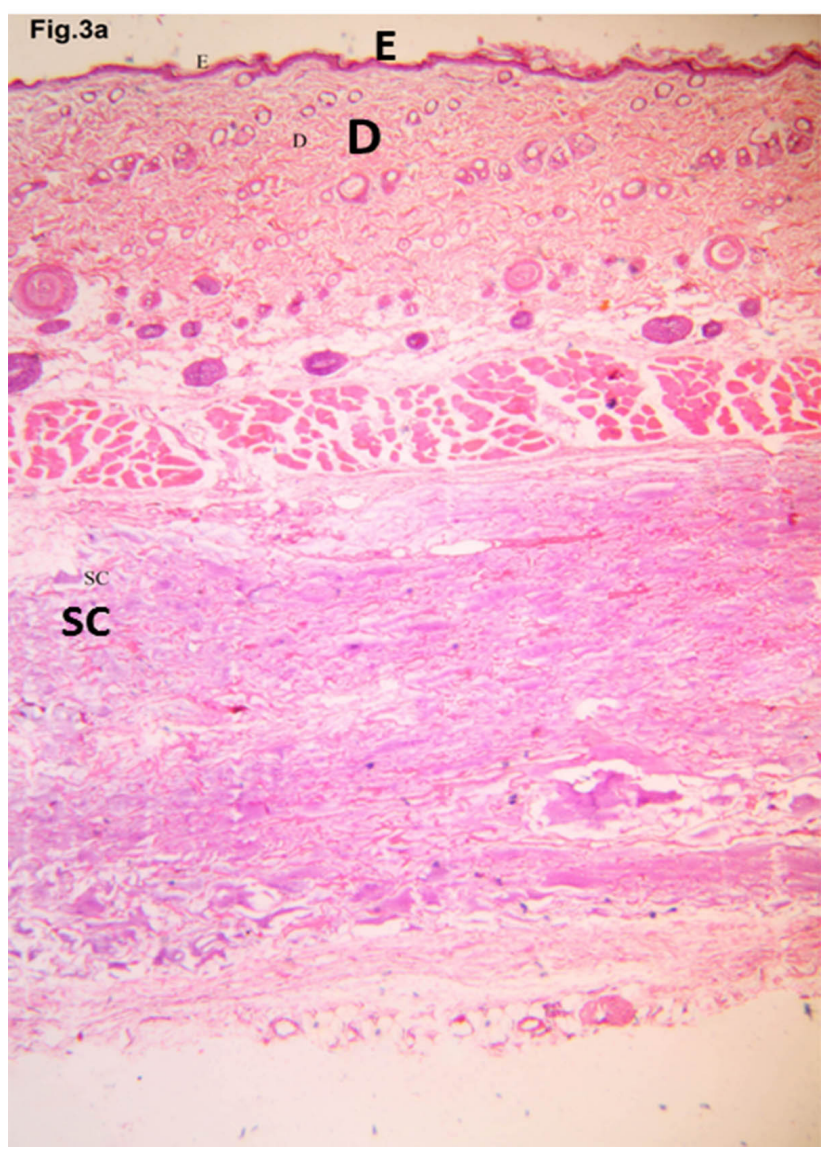

Fig.3a: A photomicrograph of a section in rat's thin skin of subgroup IIb showing the epidermis (E) and the dermis (D). An apparent increase in thickness of subcutaneous tissue (SC) is obvious. (Subgroup IIb: H\&E $\mathrm{x} 40$ ) 


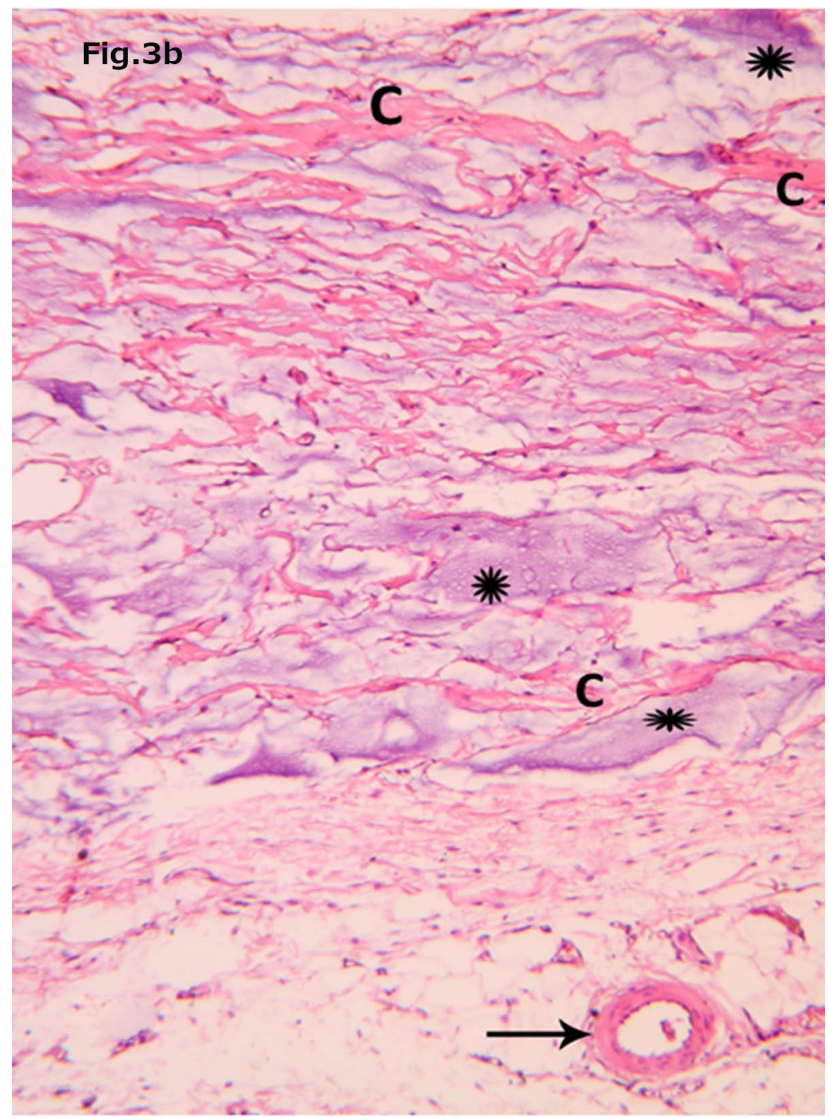

Fig.3b: Higher magnification of the previous section showing an increase in collagen fibers (C) around areas of injected $\mathrm{HA}(*)$ in the subcutaneous tissue.Notice blood vessels ( $\uparrow$ ). (Subgroup IIb: H\&E x 400)

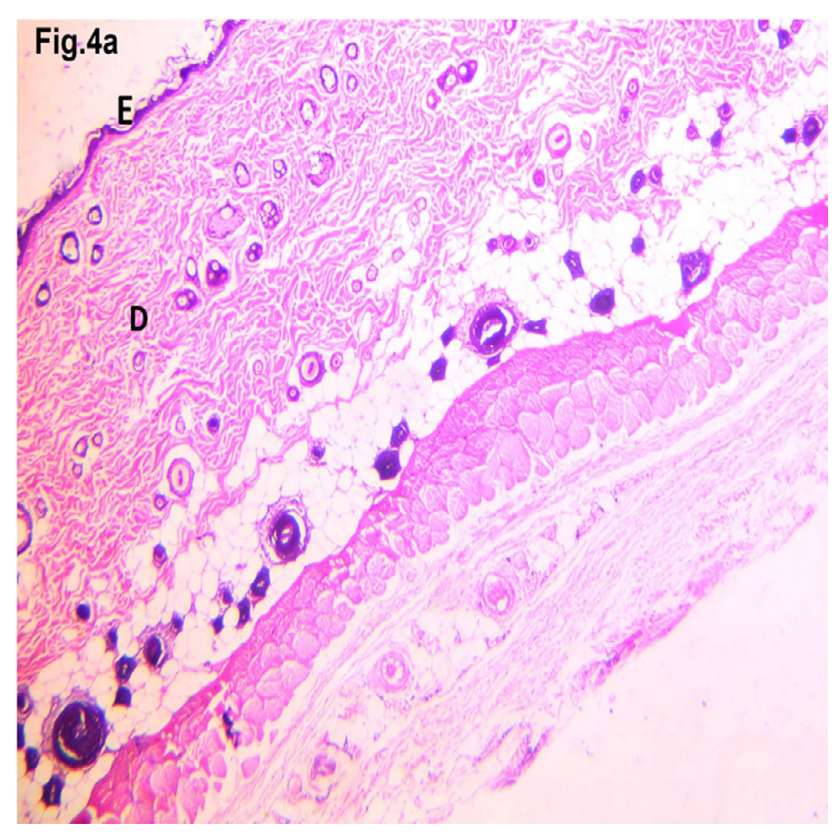

Fig.4a: A photomicrograph of a section in rat's thin skin of subgroup IIc showing epidermis (E), dermis(D) and subcutaneous tissue. An apparent increase in the thickness of the subcutaneous tissue is obvious. (Subgroup IIc: H\&E x 40)

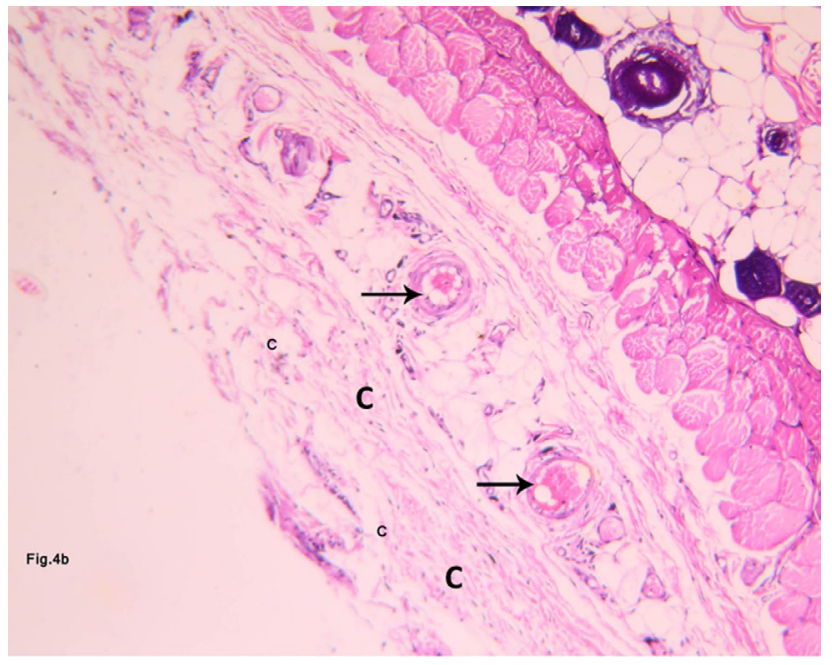

Fig.4b: Higher magnification of the previous section showing decrease of fluid spaces with apparent decrease in thickness of the subcutaneous tissue. Notice numerous blood vessels with different sizes $(\uparrow)$ between collagen fibers (C). (Subgroup IIc: H\&E x 400)

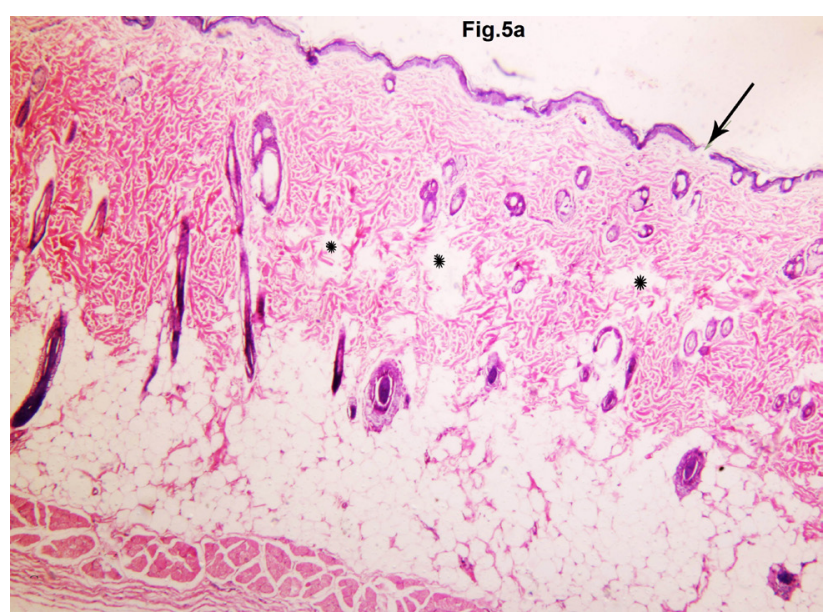

Fig.5a: A photomicrograph of a section in rat's thin skin of subgroup IIIa showing focal areas of epidermal discontinuation $(\uparrow)$. The dermis shows focal areas of collagen loss $(*)$ of variable sizes.

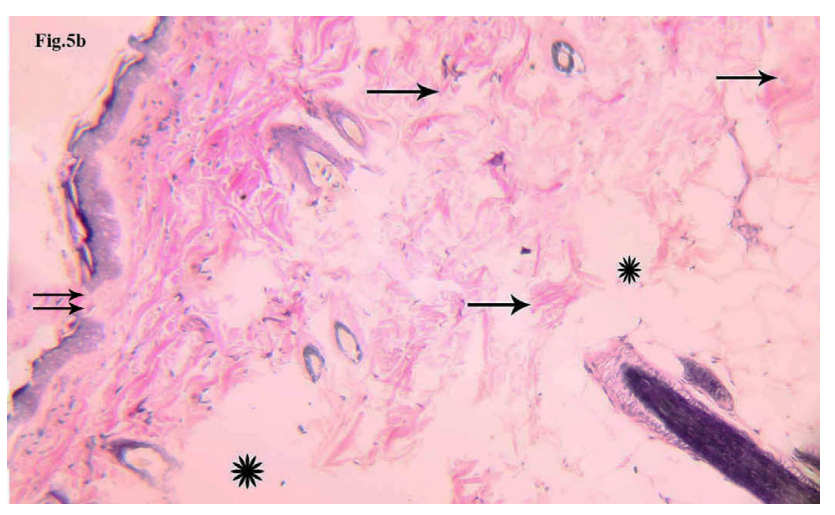

Fig.5b: Higher magnification showing discontinuation of the epidermis $(\uparrow \uparrow)$, disorganization of collagen fibers and hair follicles $(\uparrow)$. Notice loss of collagen fibers in reticular layer (*). (Subgroup IIIa: H\&E x 400) 


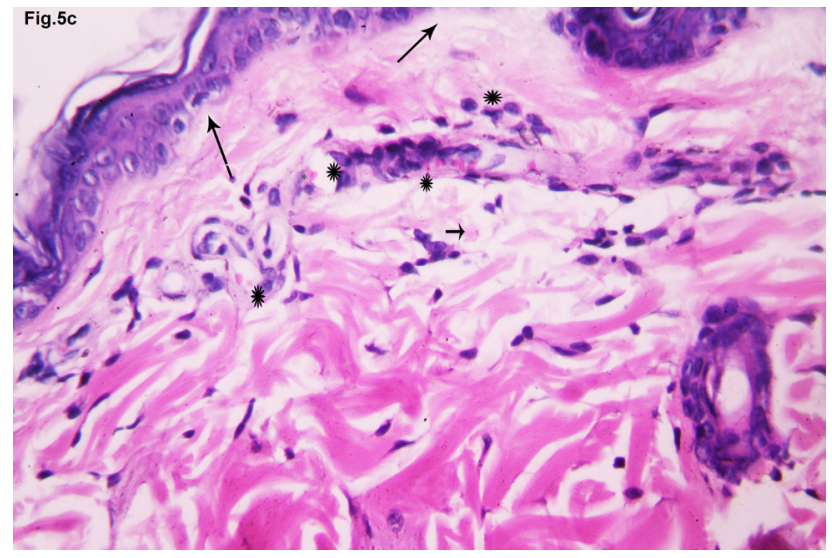

Fig.5c: A photomicrograph of a section in rat's thin skin of subgroup IIIa showing loss of collagen fibers in the papillay layer $(\uparrow)$ and mononuclear cellular infiltration in the dermis $(*)$. (Subgroup IIIa: H\&E x 400)

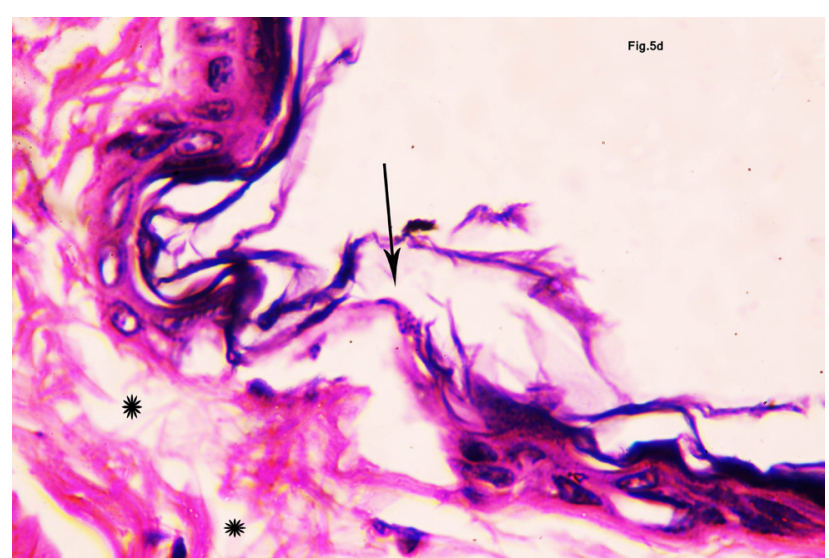

Fig.5d: A photomicrograph of a section in rat's thin skin of subgroup IIIa showing disorganization of the epidermis with focal loss of the epidermal cells $(\uparrow)$. An apparent reduction of the epidermal thickness is obvious. Notice the spaces in the papillary layer of the dermis (*). (Subgroup IIIa: H\&E x 1000)

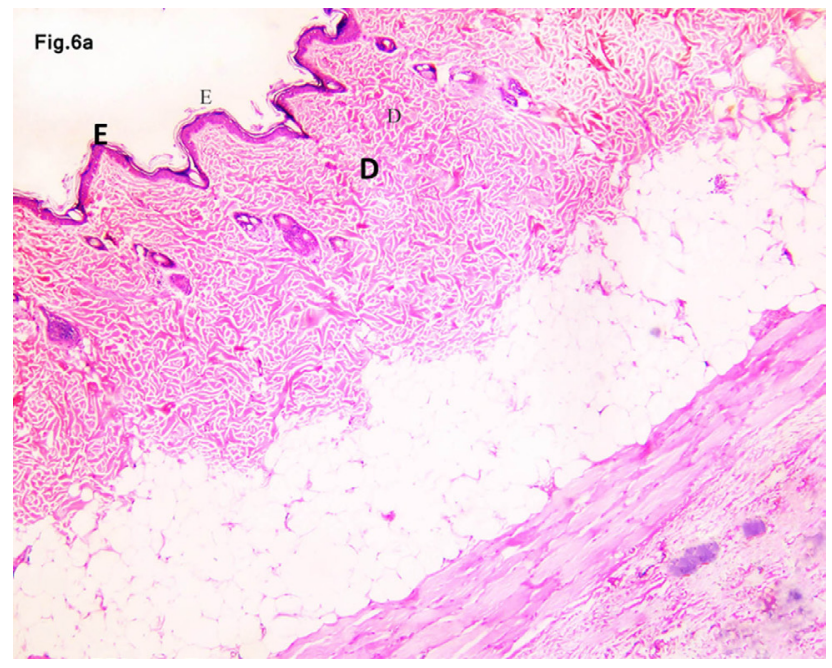

Fig.6a: A photomicrograph of a section in rat's thin skin of subgroup IIIb showing epidermis (E), dermis (D) and subcutaneous tissue. The dermis contains closely packed collagen fibers. Increase in the thickness of the subcutaneous tissue is seen. (Subgroup IIIb: H\&E x 40)

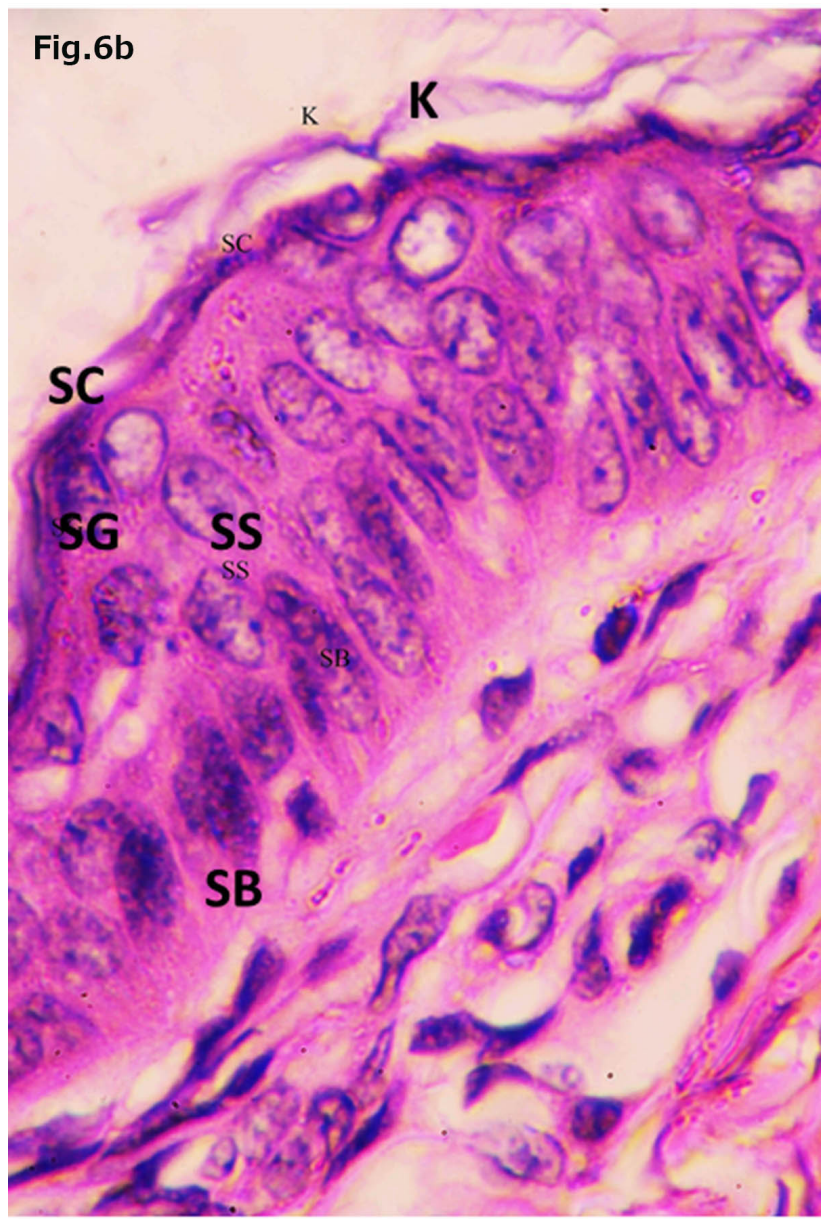

Fig.6b: Higher magnification of the previous section showing the layers of the epidermis stratum basale (SB), Stratum spinosum (SS), Stratum granulosum (SG), Stratum corneum (SC) and the covering acidophilic keratin scales (K). (Subgroup IIIb: H\&E x 1000)

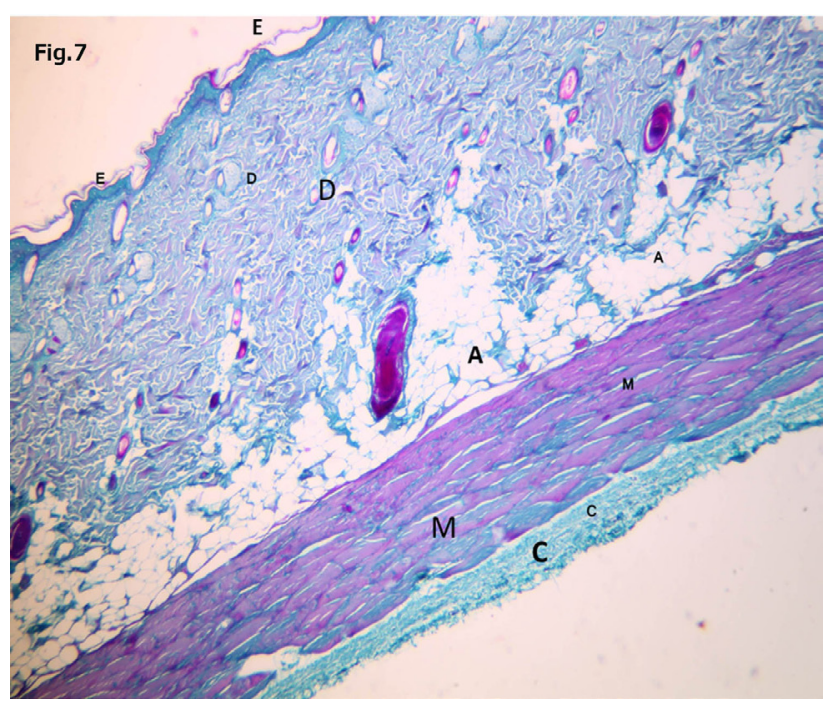

Fig.7: A photomicrograph of a section in rat's thin skin of group I showing epidermis(E), dermis(D) and subcutaneous tissue .The subcutaneous tissue contains adipose tissue (A), thin sheet of skeletal muscle fibers(M) and few collagen fibers (C). (Control group, Masson's trichrome x 40) 


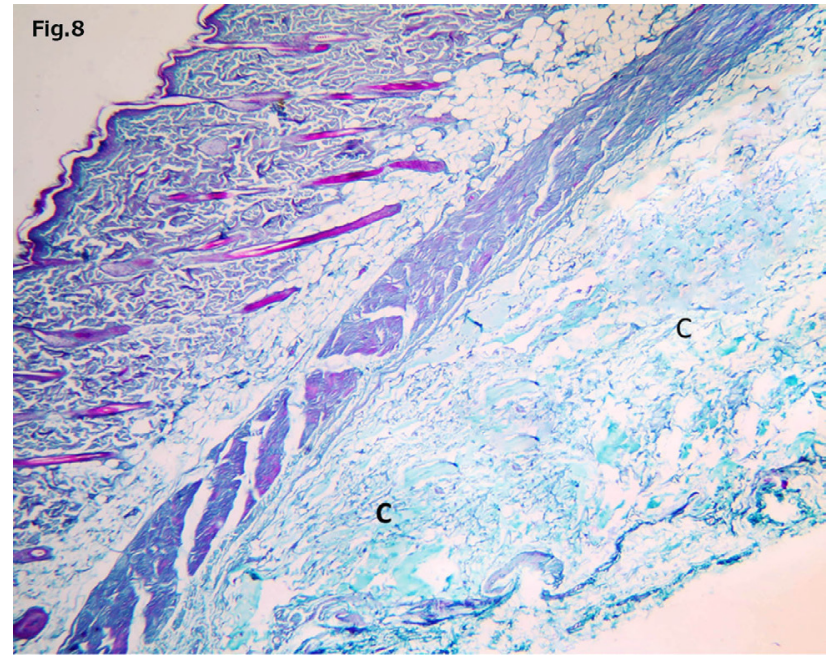

Fig.8: A photomicrograph of a section in rat's thin skin of subgroup IIa showing an apparent increase of collagen fibers (C) in the subcutaneous layer. (Subgroup IIa, Masson's trichrome x 40)

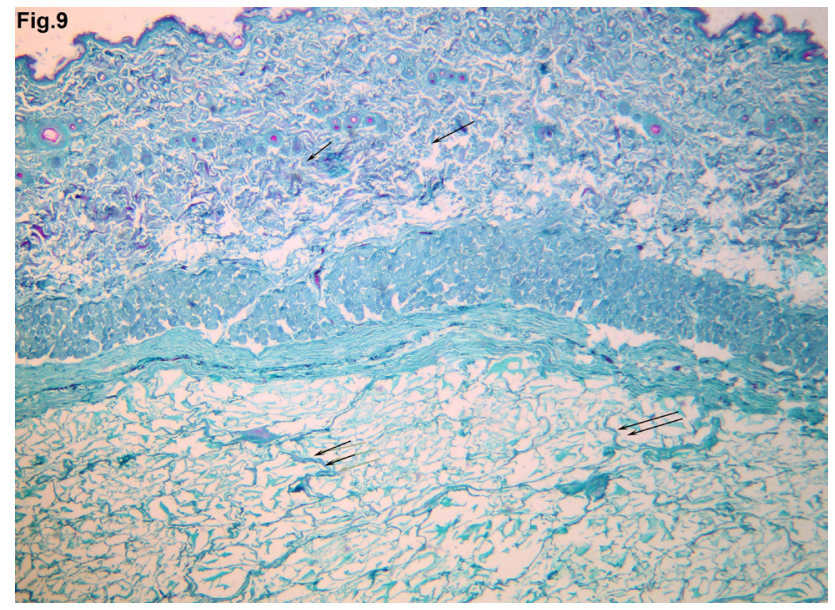

Fig.9: A photomicrograph of a section in rat's thin skin of subgroup IIb showing an apparent increase of collagen fibers in the subcutaneous layer $(\uparrow \uparrow)$ as well as in the dermis $(\uparrow)$. (Subgroup IIb Masson's trichrome $\mathrm{x}$ 40)

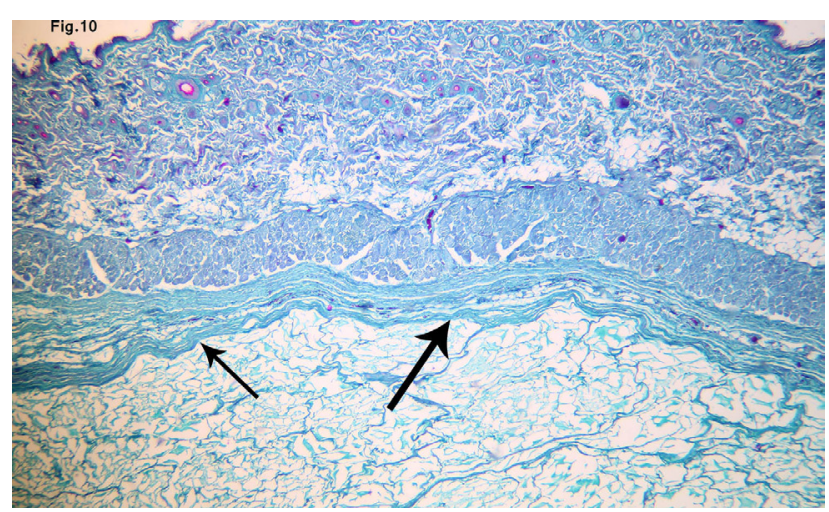

Fig.10: A photomicrograph of a section in rat's thin skin of subgroup IIc showing the collagen fibers closely packed forming a continuous layer in the subcutaneous tissue $(\uparrow)$. (Subgroup IIc, Masson's trichrome x40)

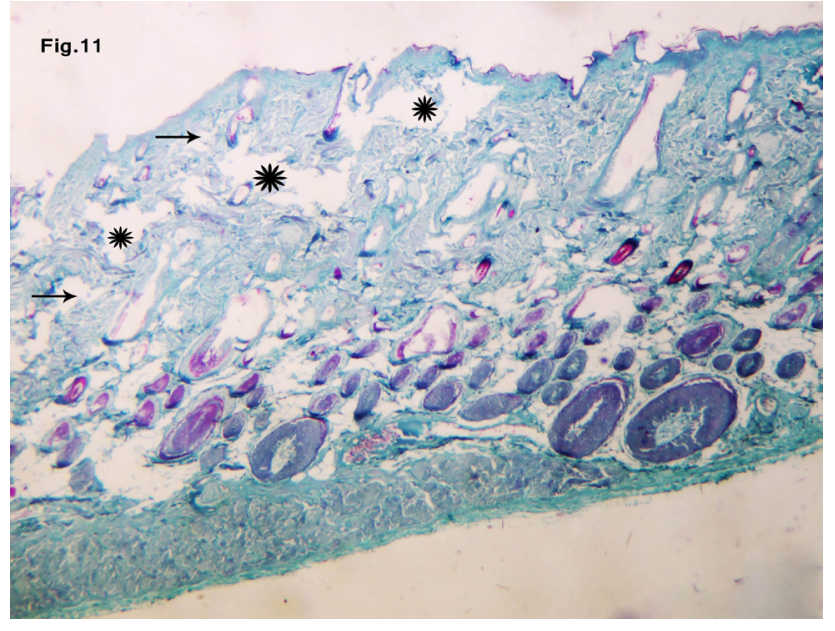

Fig.11: A photomicrograph of a section in rat's thin skin of subgroup III showing disorganized collagen $(\uparrow)$ with spaces of collagen fiber loss $(*)$. (Subgroup IIIa, Masson's trichrome x 40)

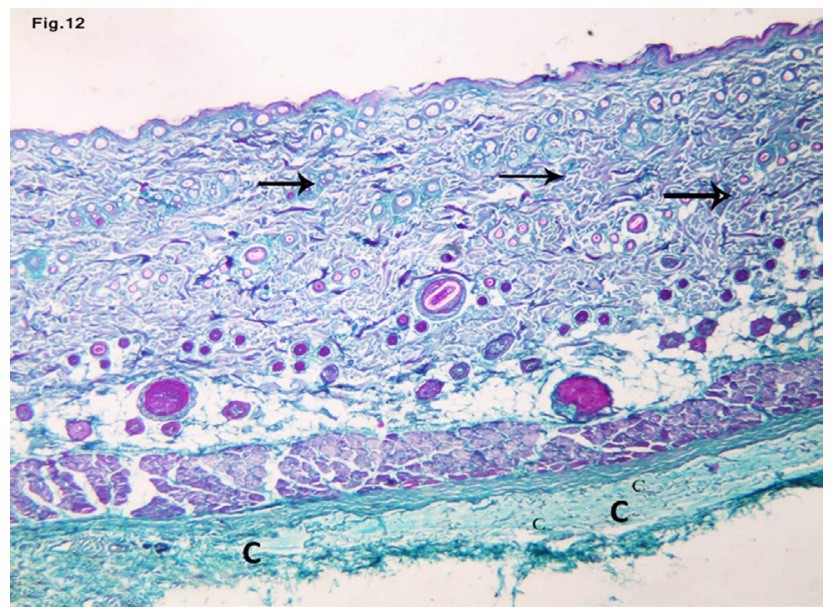

Fig.12: A photomicrograph of a section in rat's thin skin of subgroup IIIb showing closely packed collagen fibers in the papillary and reticular layers of the dermis $(\uparrow)$ and subcutaneous layer (C). (Subgroup IIIb, Masson's trichrome x 40)

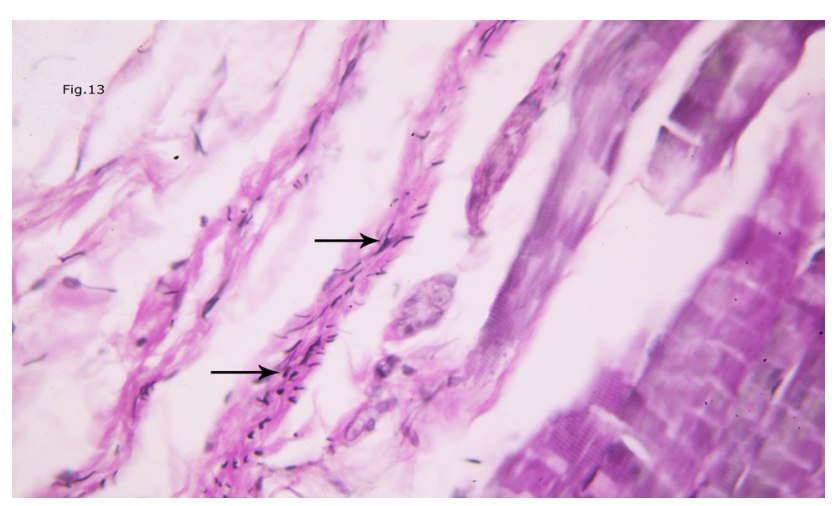

Fig.13: A photomicrograph of a section in rat's thin skin of group I showing short branched and thin elastic fibers $(\uparrow)$ in the subcutaneous region. (Control group, Verhoeff Van-Gieason x400) 


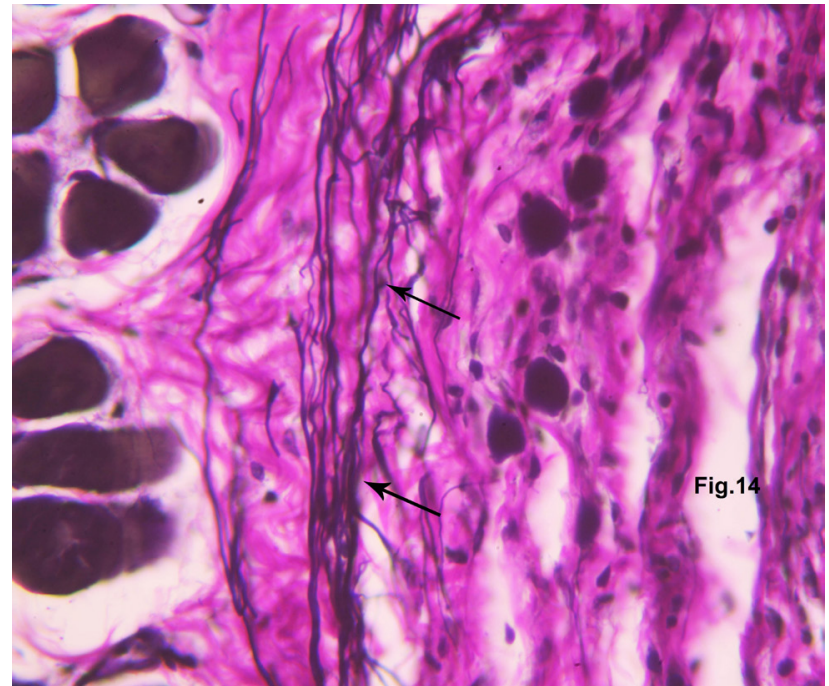

Fig.14: A photomicrograph of a section in rat's thin skin of subgroup IIa showing long branched parallel elastic fibers $(\uparrow)$ in the subcutaneous tissue. (Subgroup IIa, Verhoeff Van-Gieason x400)

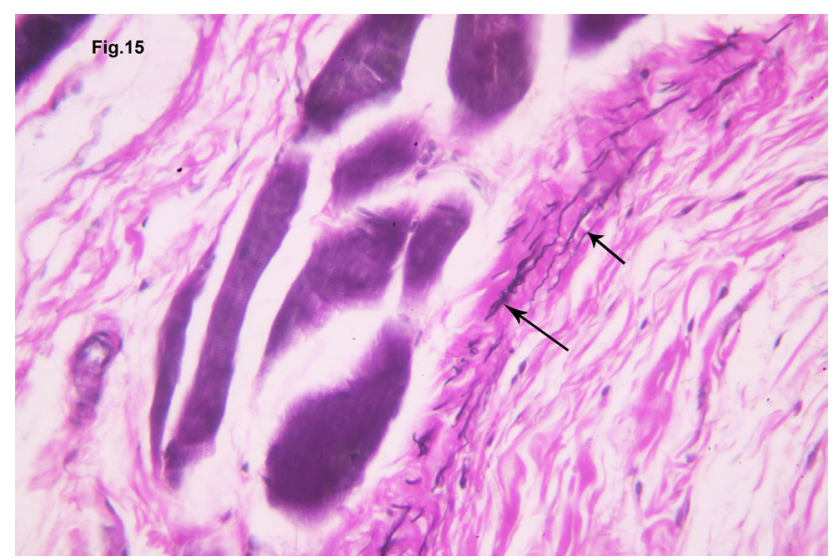

Fig.15: A photomicrograph of a section in rat's thin skin of subgroup IIb showing thin branched parallel elastic fibers $(\uparrow)$ in the subcutaneous tissue. (Subgroup IIb, Verhoeff Van-Gieason x400)

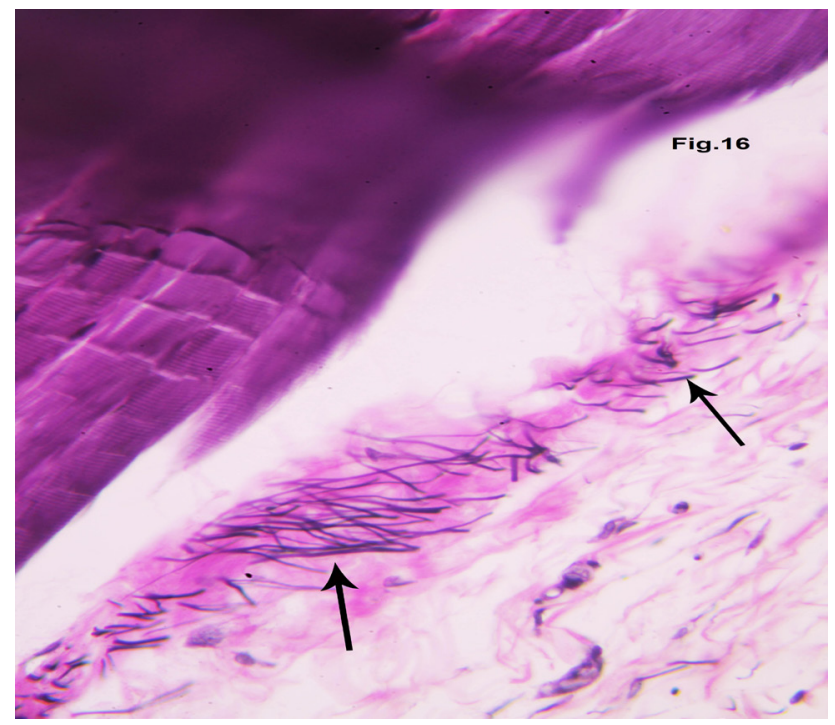

Fig.16: A photomicrograph of a section in rat's thin skin of subgroup IIc showing short branched elastic fibers $(\uparrow)$ in the subcutaneous region. (Subgroup IIc, Verhoeff Van-Gieason x400)

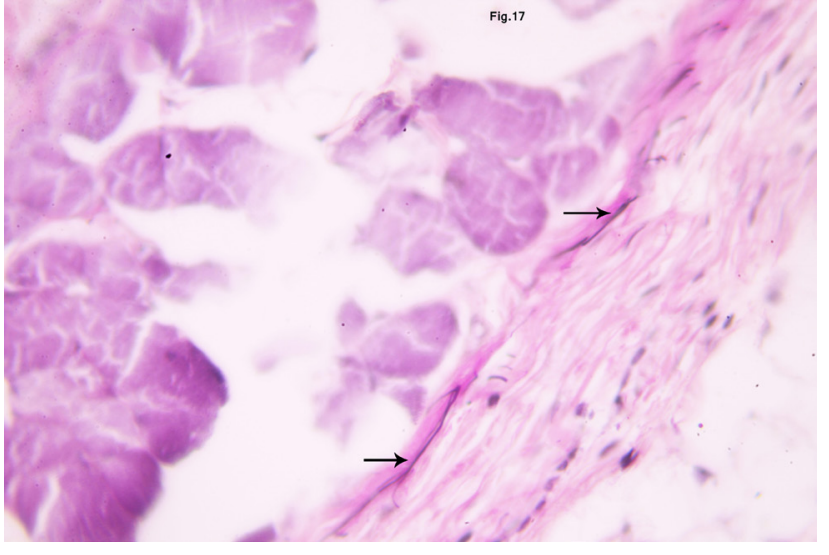

Fig.17: A photomicrograph of a section in rat's thin skin of subgroup IIIa showing few faint elastic fibers in the dermis $(\uparrow)$. (Subgroup IIIa, Verhoeff Van-Gieason $\mathrm{x} 400$ )

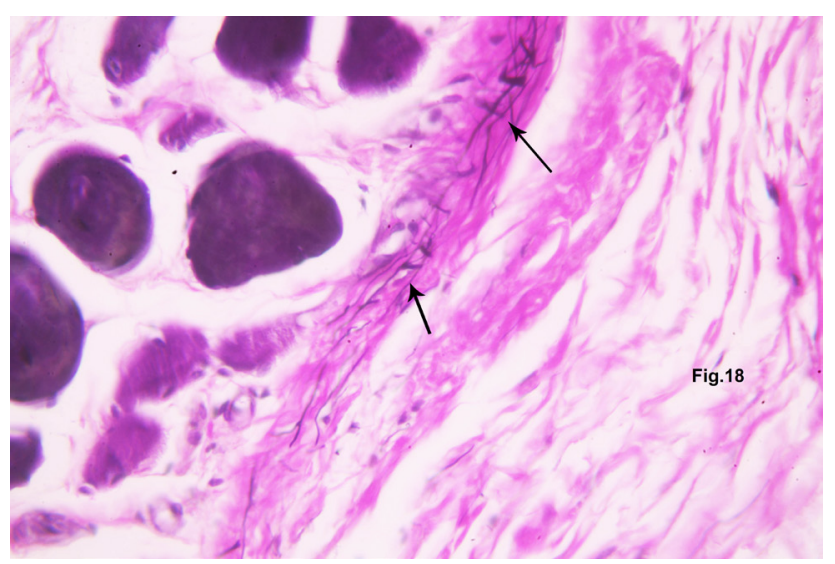

Fig.18: A photomicrograph of a section in rat's thin skin of subgroup IIIb showing thin branched elastic fibers $(\uparrow)$ in the subcutaneous tissue. (Subgroup IIIb, Verhoeff Van-Gieason x400)

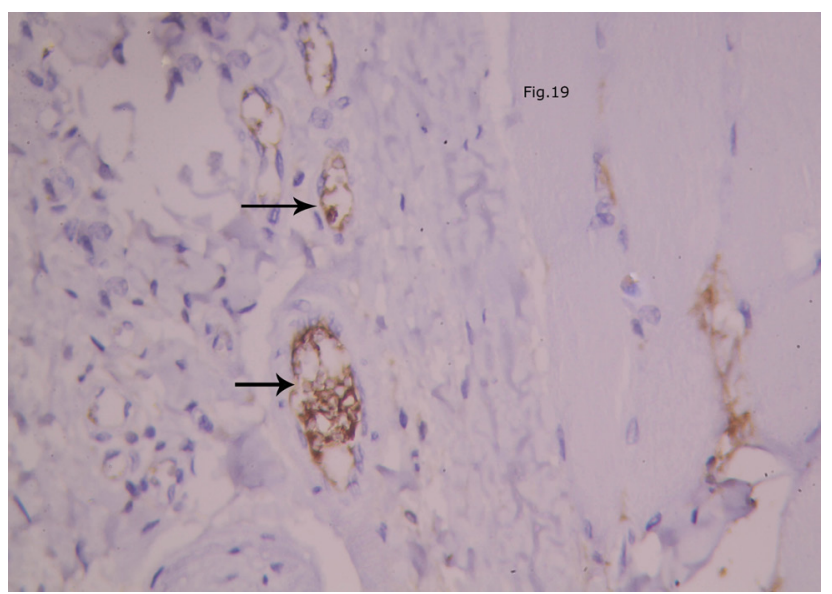

Fig.19: A photomicrograph of a section in rat's thin skin of group I showing faint positive reaction for CD34 in the endothelium of blood capillaries $(\uparrow)$. (Control group: Streptavidin-biotin peroxidase x 400) 


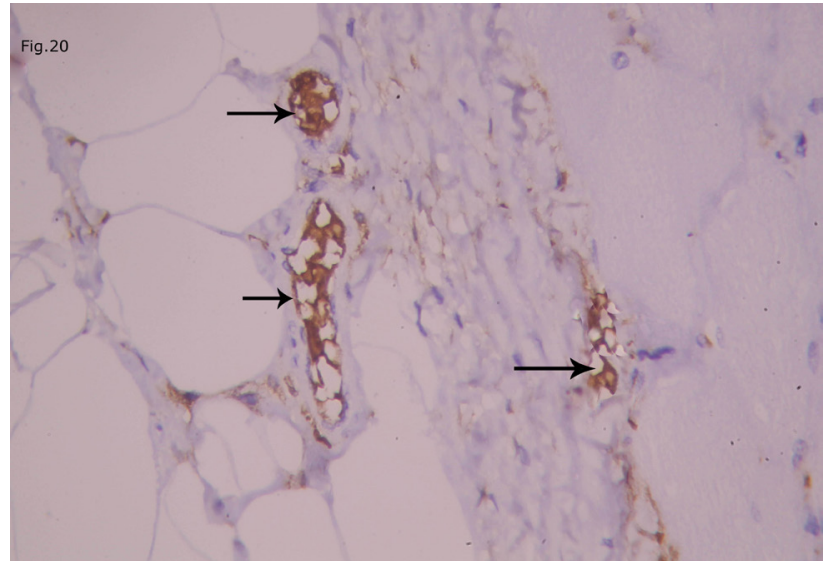

Fig.20: A photomicrograph of a section in rat's thin skin of subgroup IIa showing an apparent increase of the positive reaction for CD34 in the endothelium of subcutaneous blood capillaries $(\uparrow)$. (Subgroup IIa: Streptavidin-biotin peroxidase $\mathrm{x} 400$ )

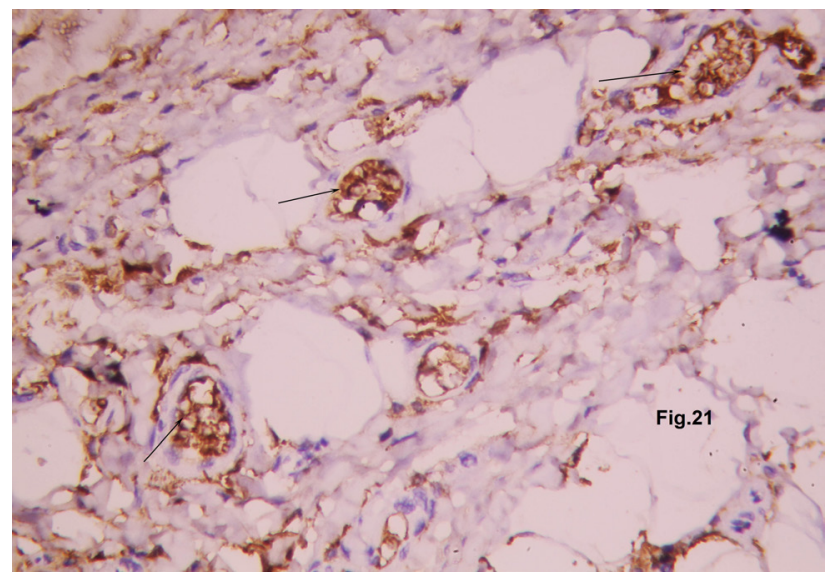

Fig.21: A photomicrograph of a section in rat's thin skin of subgroup IIb showing strong brownish positive immune reaction for CD34 antibody in the endothelium of blood vessels $(\uparrow)$ of the subcutaneous tissue. Notice the numerous blood vessels at the site of HA injection. (Subgroup IIb: Streptavidin-biotin peroxidase $\mathrm{x} 400$ )

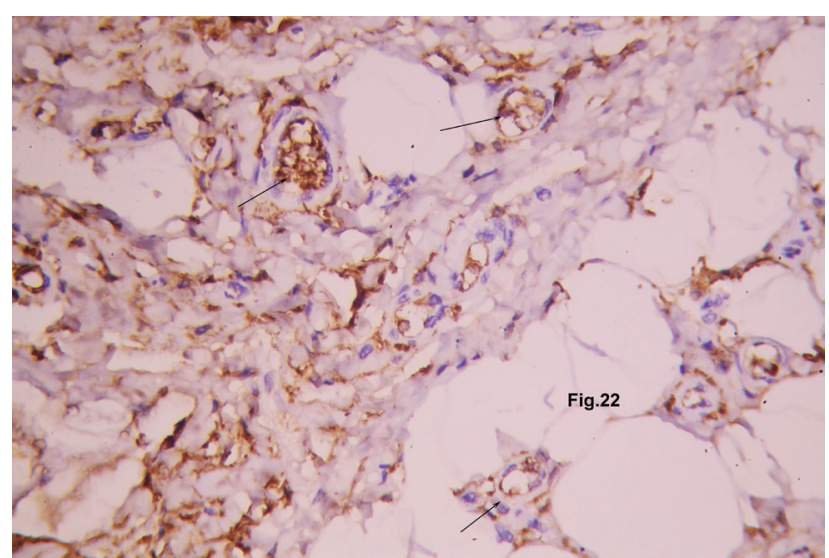

Fig.22: A photomicrograph of a section in rat's thin skin of subgroup IIc showing strong extensive brownish positive immune reaction for CD34 antibody in the endothelium of blood vessels $(\uparrow)$ in the subcutaneous tissue . (Subgroup IIc: Streptavidin-biotin peroxidase x 400)

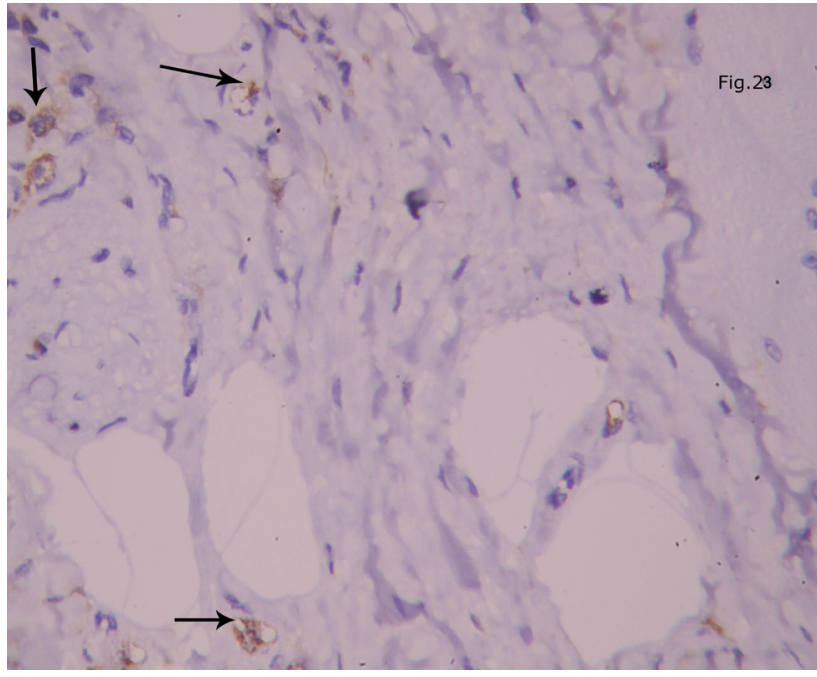

Fig.23: A photomicrograph of a section in rat's thin skin of subgroup III showing faint immune reaction for CD34 antibody in the endothelium of the few blood capillaries $(\uparrow)$. (Subgroup IIIa: Streptavidin-biotin peroxidase $\mathrm{x} 400$ )

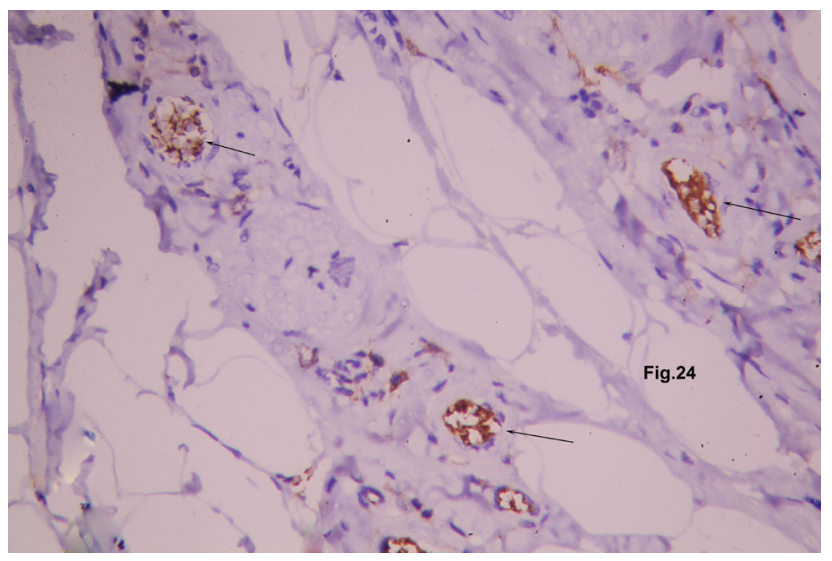

Fig.24: A photomicrograph of a section in rat's thin skin of subgroup IIIb showing an apparent increase in the positive immune reaction $(\uparrow)$ for CD34 antibody in the endothelium of the blood vessels at the subcutaneous tissue. Notice the apparent increase in these blood vessels. (Subgroup IIIb: Streptavidin-biotin peroxidase x 400)

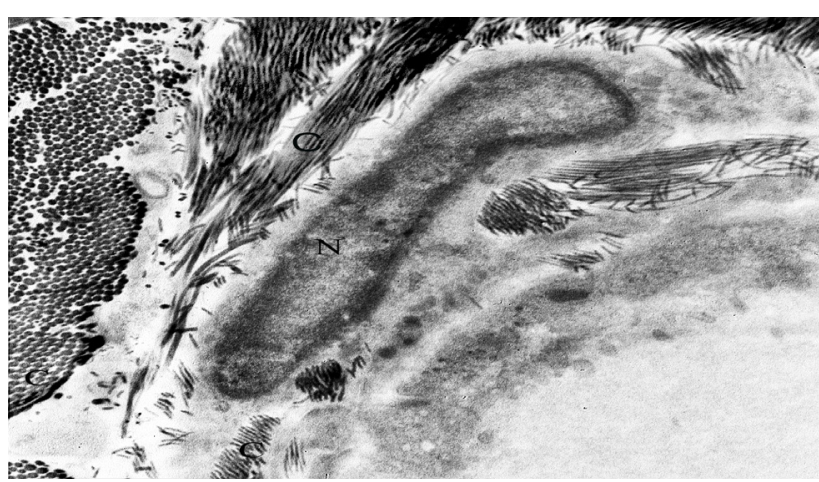

Fig.25: An electron micrograph of an ultrathin section in the subcutaneous tissue of rat's thin skin of the group I showing inactive fibroblast with elongated nucleus $(\mathrm{N})$ and few organelles in the cytoplasm. Notice collagen fibers (C) surrounding the fibroblast. (Group I,TEM x 12000) 


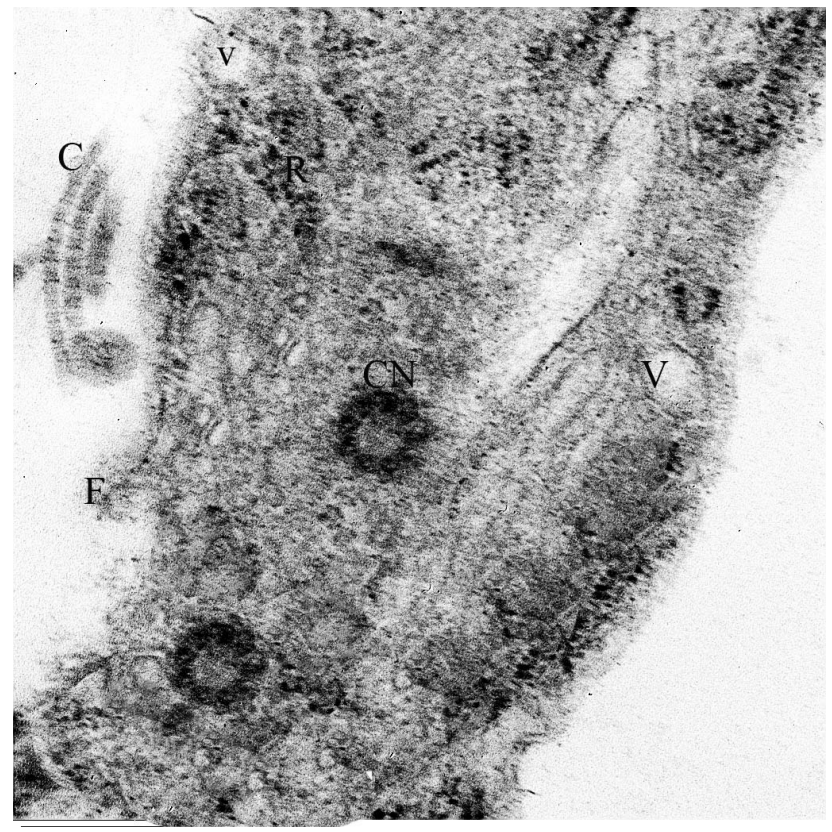

Fig.26: An electron micrograph of an ultrathin section in the subcutaneous tissue of rat's thin skin of the subgroup IIa showing a part of cytoplasm of immature fibroblast. It contains well developed rough endoplasmic reticulum $(\mathrm{R})$, two centrioles $(\mathrm{CN})$, and multiple vesicles $(\mathrm{V})$. Notice small filopodium (F) extends from the surface of the cell. Few collagen fibers $(\mathrm{C})$ with their characteristic axial periodicity are seen beside the cell. (Subgroup IIa, TEM x 25000)

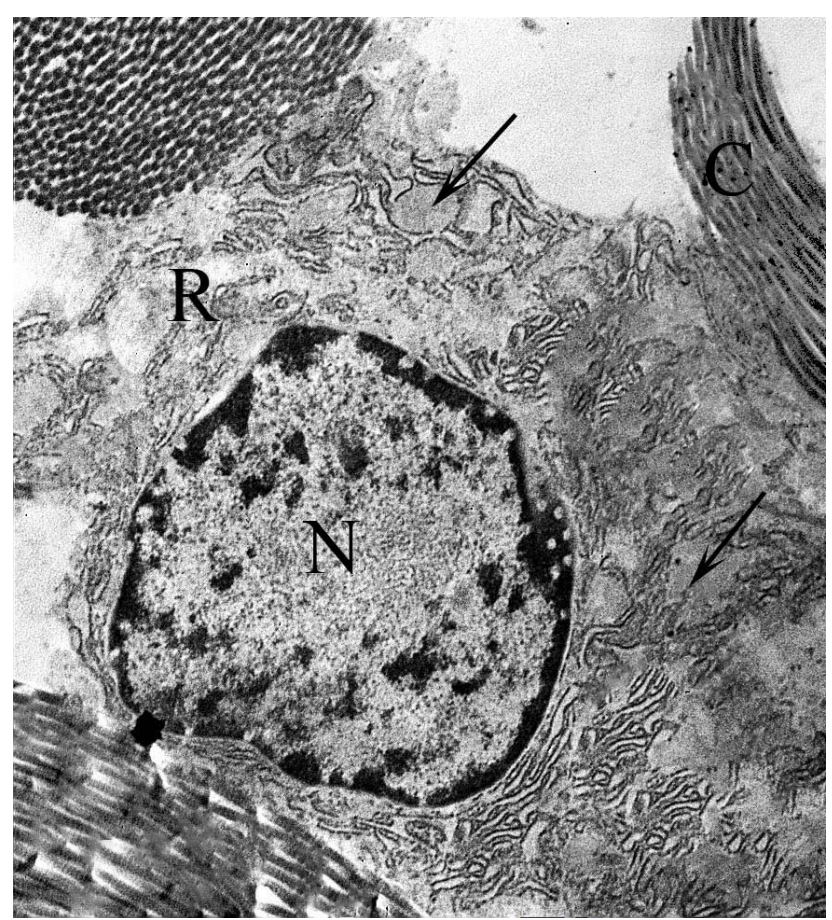

Fig.27: An electron micrograph of an ultrathin section in the subcutaneous tissue of rat's thin skin of the subgroup IIb showing active fibroblast with an euchromatic nucleus (N) with peripheral heterochromatin Cytoplasm of the fibroblast contains numerous dilated cisternae of rough endoplasmic reticulum (R). Notice regularly arranged collagen fibers with their axial periodicity (C) beside the cell. (Subgroup IIb, TEM x 12000)

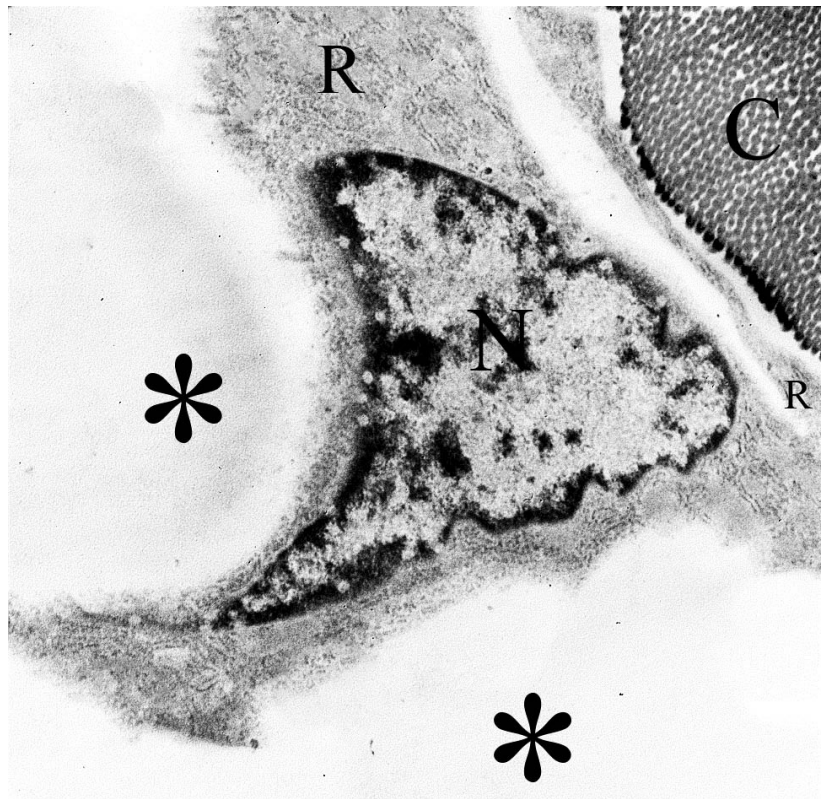

Fig.28: An electron micrograph of an ultrathin section in the subcutaneous tissue of rat's thin skin of the subgroup IIc showing active fibroblast compressed by fluid accumulation $\left(^{*}\right)$. (Subgroup IIc, TEM x 12000)

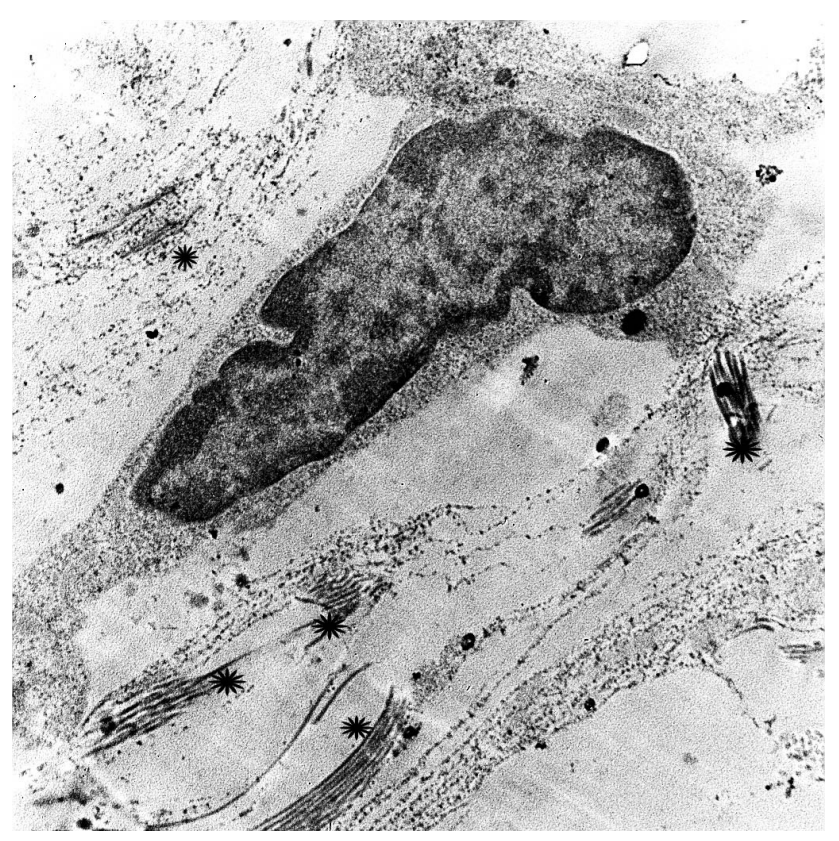

Fig.29: An electron micrograph of an ultrathin section in the subcutaneous tissue of rat's thin skin of the subgroup IIIa showing inactive fibroblast with flat hyperchromatic nucleus and small cytoplasm surrounded by few widely dispersed irregular collagen fibers $\left(^{*}\right)$. (Subgroup IIIa: TEM x 12000) 


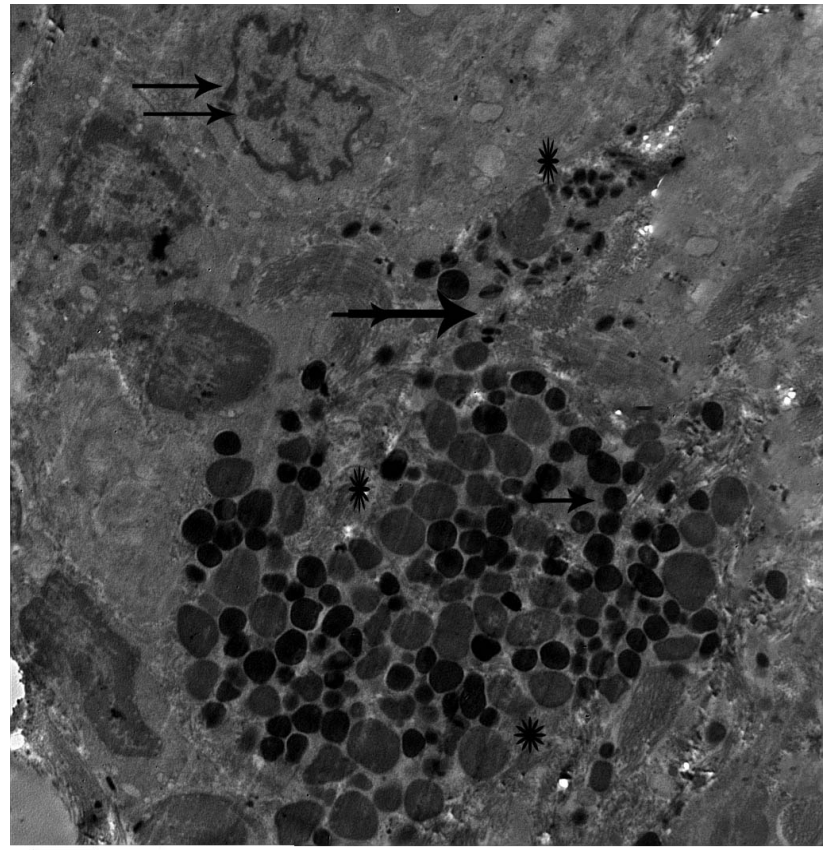

Fig.30: An electron micrograph of an ultrathin section in the dermis of rat's thin skin of the subgroup IIIa showing nuclei of fibroblasts (*). Notice Inflammatory cells $(\uparrow)$ with cytoplasm full of granules. (Subgroup IIIb: TEM x 12000)

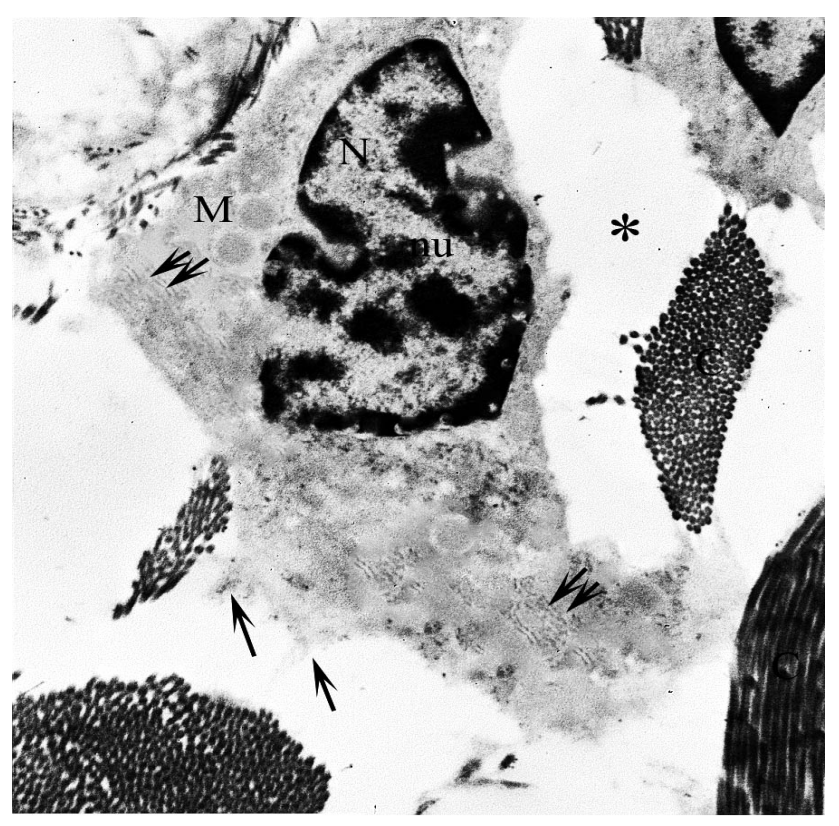

Fig.31: An electron micrograph of an ultrathin section in the subcutaneous tissue of rat's thin skin of the subgroup IIIb showing an active fibroblast. It has a folded nucleus $(\mathrm{N})$.Nucleolus (nu) is clear in the center with mitochondria (M) and rough endoplasmic reticulum $(\uparrow)$ in its cytoplasm and surrounded by collagen fibers(C) . (Subgroup IIIb: TEM x 12000)

Table 1: Thickness of different parts of skin, area \% of collagen, elastic fibers and CD34 in different animals groups

\begin{tabular}{|c|c|c|c|c|c|c|}
\hline Variable & Group I & Subgroup IIa & Subgroup IIb & Subgroup IIc & Subgroup IIIa & Subgroup IIIb \\
\hline Epidermal thickness & $26.09 \pm 3.49$ & $25.92 \pm 5.38$ & $25.10 \pm 3.24$ & $25.48 \pm 3.94$ & $6.81 \pm 2.03^{\text {af }}$ & $25.94 \pm 3.45^{\mathrm{e}}$ \\
\hline Dermal thickness & $954.25 \pm 69.12$ & $918.62 \pm 91.24$ & $942.48 \pm 82.82$ & $902.97 \pm 87.80$ & $767.52 \pm 89.34^{\mathrm{af}}$ & $900.75 \pm 86.34^{\mathrm{e}}$ \\
\hline Subcutaneous thickness & $97.80 \pm 19.60^{\mathrm{bcd}}$ & $1759.09 \pm 17.23^{\text {ae }}$ & $1592.97 \pm 36.88^{\mathrm{ae}}$ & $1063.15 \pm 136.53^{\mathrm{abce}}$ & $71.54 \pm 12.79^{a f}$ & $671.12 \pm 100.36^{\mathrm{ae}}$ \\
\hline Collagen area $\%$ & $14.60 \pm 7.03^{\mathrm{bcd}}$ & $22.08 \pm 8.07^{\mathrm{ae}}$ & $33.39 \pm 10.96^{\mathrm{ae}}$ & $38.89 \pm 8.80^{\text {abce }}$ & $10.41 \pm 3.49^{\mathrm{af}}$ & $25.78 \pm 9.01^{\mathrm{ae}}$ \\
\hline Elastic area \% & $0.31 \pm 0.15^{\text {bcd }}$ & $4.60 \pm 1.20^{\mathrm{ae}}$ & $2.47 \pm 1.98^{\text {ae }}$ & $1.31 \pm 0.33^{\text {abce }}$ & $0.28 \pm 0.20^{\text {af }}$ & $2.56 \pm 1.27^{\mathrm{ae}}$ \\
\hline CD34 area \% & $0.87 \pm 0.45^{\text {bcd }}$ & $3.40 \pm 2.60^{\mathrm{ae}}$ & $3.34 \pm 2.29^{\mathrm{ae}}$ & $2.41 \pm 0.45^{\text {abce }}$ & $0.35 \pm 0.21^{\text {af }}$ & $1.41 \pm 0.20^{\mathrm{ae}}$ \\
\hline
\end{tabular}

a: significance of difference by LSD of control group I at least $p<0.05$.

$\mathrm{b}$ : significance of differences by LSD of group IIa at least $p<0.05$.

c: significance of differences by LSD of subgroup IIb at least $p<0.05$.

d: significance of differences by LSD of subgroup IIc at least $p<0.05$.

e: significance of differences by LSD of subgroup IIIa at least $p<0.05$.

f: significance of differences by LSD of subgroup IIIB at least $p<0.05$.

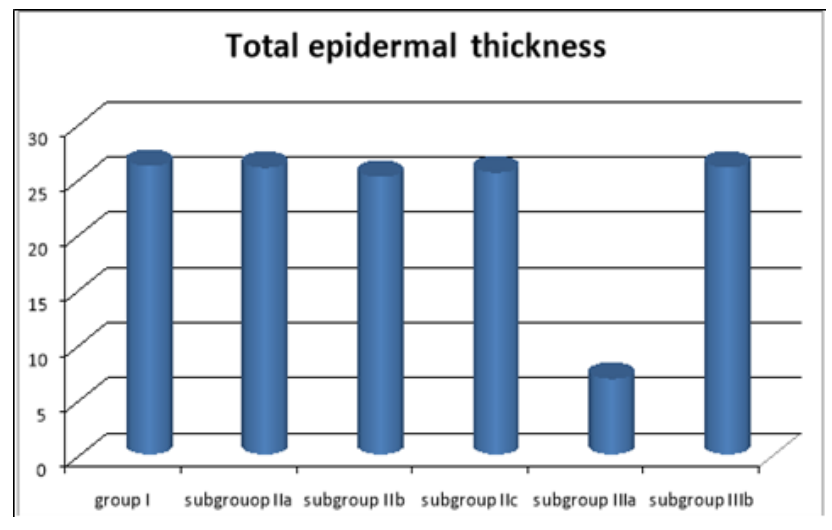

Histogram 1: Differences in the total epidermal thickness

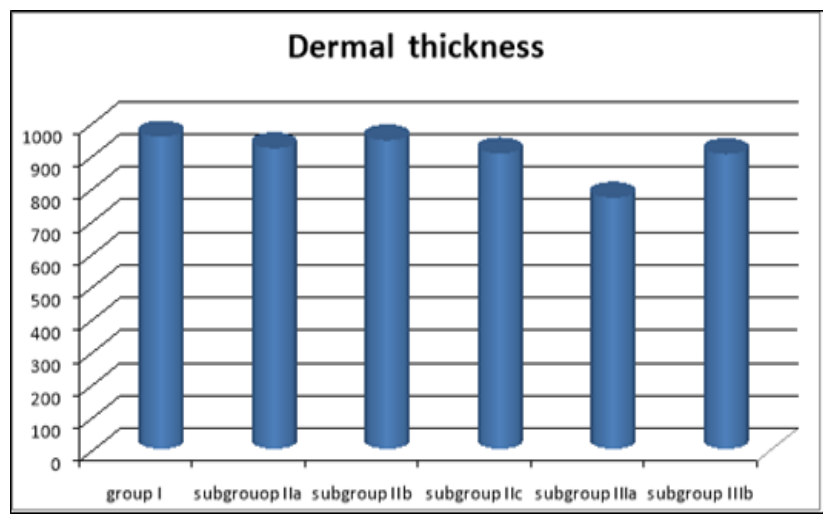

Histogram 2: Differences in the dermal thickness 


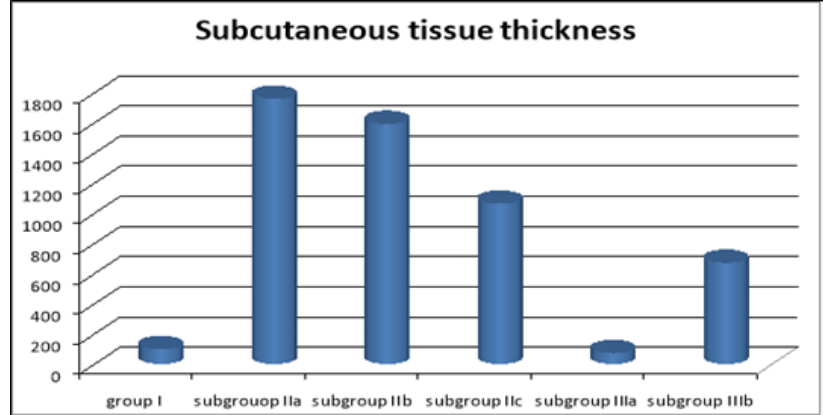

Histogram 3: Differences in the subcutaneous tissue thickness

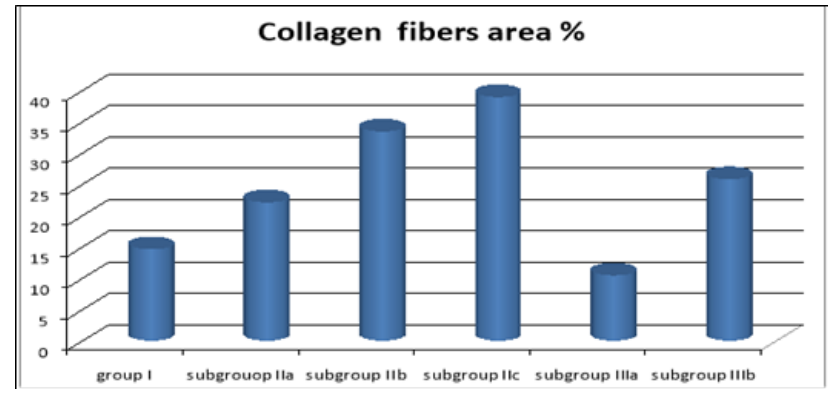

Histogram 4: Differences in the collagen fibers area \%

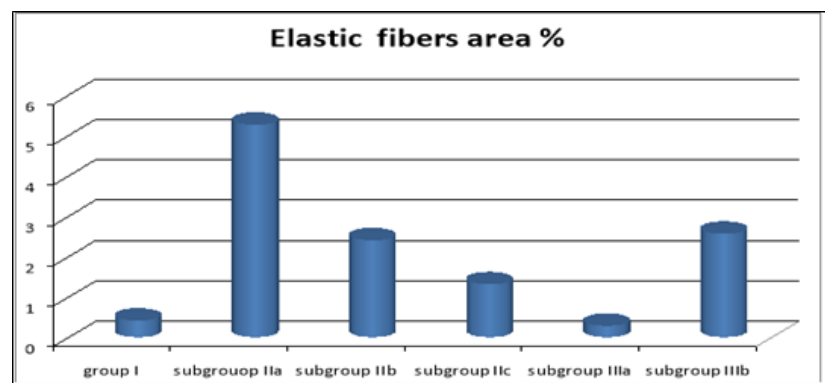

Histogram 5: Differences in the elastic fibers area \%

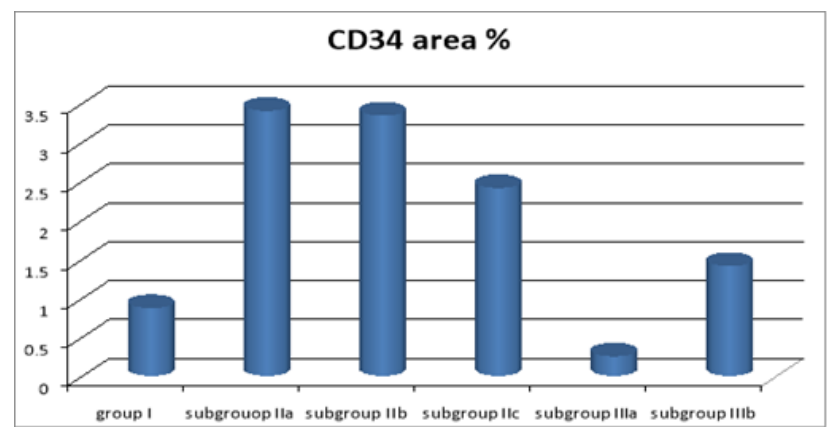

Histogram 6: Differences in the CD34 area \%

\section{DISCUSSION}

In recent years, the popularity of minimally invasive cosmetic procedures, including the use of dermal fillers to hide wrinkle ${ }^{[11]}$. Beauty is a specific proportion system that takes into account facial height, width and symmetry, according to some plastic surgeons ${ }^{[12]}$. Dermal fillers are mainly used to create volume or to reverse any soft tissue loss due to disease or age ${ }^{[13]}$.
In the current study,skin specimens from subgroup IIa were taken after seven days to be sure that the filler injected in its site and to observe the early reaction of the filler. This came in accordance with a similar study that analyzed histological sections of various HA formulations on the same day, and 14 days after injection to show filler distribution ${ }^{[14]}$.

In the present study, sections of thin skin of animals of subgroup IIa revealed an significant increase in thickness of the subcutaneous tissue. Basophilic areas of fluid accumulation with few collagen fibers were detected. While in rats of subgroups IIb obvious increase in thikness due to actually collagen fibers formation between fluid accumultion.In subgroup IIc, decrease in thickness of subcutaneous tissue due to disappearance of fluid spaces in comparison to IIa and IIb. Some authors explained that a hyaluronic acid based filler can stretch neighboring dermal fibroblasts due to its absorption of interstitial fluid in the first few weeks after injection ${ }^{[15]}$. These results were confirmed by EM examination of thin skin of rats of subgroup IIa which revealed numerous fibroblasts with euochromatic nuclei in the dermis and subcutaneous tissue. Their cytoplasm contained numerous mitochondria and well developed rough endoplasmic reticulum (rER). These fibroblasts were surrounded by regularly arranged collagen fibers with their characteristic axial periodicity. Cells with widely separated centrioles (immature fibroblast) in subgroup IIa could be detected.These cells might belong to the several stem cells niches present in the skin.Some authors proved that hyaluronan influence adhesion, proliferation, differentiation, and migration of MSCs. This occurs through several newly discovered genetic signaling mechanisms that involve binding to specific cellular receptors ${ }^{[16]}$. Numerous rough endoplasmic reticulum with dilated cisternae were observed in the fibroblasts of rats of subgroups IIb and IIc. Mechanical stress by fluid accumulation lead to fibroblast activation as noticed in subgroup IIc. Some authors detected many stretched fibroblasts in between the connective tissue fibers surrounding spaces that contained HA after 4 and 13 weeks of injection. They also concluded that many stretched fibroblasts contained abundant rough endoplasmic reticulum, indicating a heightened state of protein synthesis ${ }^{[17]}$. Similarly, some authors found numerous fibroblasts, collagen fibrils and elastin fibres in the dermis after HA injection ${ }^{[18]}$. Some authors proved that hyaluronan also played a role in the epithelial-mesenchymal transition in which transformation of epithelial cells into connective tissue cells ${ }^{[19]}$. Moreover, others added that these changes increase the activity of the transforming growth factor- $\beta$ pathway could stimulate fibroblasts and endothelial cells resulted in collagen, matrix and blood vessels formation in soft-tissue wound-healing processes ${ }^{[20]}$. These results were also confirmed by Masson's trichrome stained sections that showed an significant increase of collagen fibers in the dermis and subcutaneous tissue of these rats. Fibroblasts migrated into the HA filler by the 4th weeks as a result of physical stimulation. Lattice structures were created 
by fibrogenesis following the migration of fibroblasts and angiogenesis ${ }^{[20]}$. These findings came in agreement with some authors, who observed an increase in both mature collagen and newly synthesized collagen fibers at site of filler injection ${ }^{[21]}$. Moreover, some researchers confirmed that collagen fibers rapidly increased, after 4 weeks of HA injection to occupy 13.8 percent of the filled area ${ }^{[20]}$.

In the present work, long branched parallel elastic fibers were detected in the subcutaneous region of rats of both subgroups IIa and IIb, whereas, short branched elastic fibers were seen in the subcutaneous region of rats of subgroup IIc. These findings were confirmed by statistical results. Some authors proved that the presence of newly synthesized elastin fibers at the injection sites. New collagen and elastic fibers were observed to be aligned at the tissue-filler interface. They added that the expression of dermal elastin protein was significantly increased in animals injected with HA at weeks 4, 8, and 12 compared to the control and to be expressed maximally at 4 and 8 weeks after injection ${ }^{[21]}$.

In the current study, blood capillaries were seen in subgroup IIa in the subcutaneous tissue of the skin of adult rats. An significant increase in these capillaries was noticed in the subcutaneous tissue of rats following HA injection. Numerous blood capillaries were seen in rats of subgroup IIc, 90 days after HA injection. The endothelial cells of the blood capillaries, detected by immune -staining, showed positive reaction for CD34 which is primarily expressed on endothelium of small or newly formed vessels. Significant gradual increase in the positive reaction for CD34 in rats of group II was noticed in the endothelial cells of blood capillaries following HA injection. Strong reaction was observed in the numerous capillaries after 90 days following HA injection. These findings were confirmed by statistical results. Some authors proved that human transmembrane surface hematopoietic progenitor cell antigen CD34, is an important marker for vascularization and microvascular density in the tissues ${ }^{[18]}$. It was founded that HA induced proliferation of endothelial cells and tube formation during angiogenesis. This was mediated by CD44 signaling. Hyaluronan slightly increased the expression of angiogenic markers, including KDR, CD31, and $\mathrm{vWF}^{[22]}$.

In the current study, there was an significant reduction in the thickness of the epidermis, dermis and the subcutaneous tissue of aged rats of subgroup IIIa (which were injected with saline only). These findings were confirmed by statistical results. Similar results were found that a significant decrease in the maximum thickness of the epidermis and flattening of the dermo-epidermal junction were seen in age-related changes in human $\operatorname{skin}^{[23]}$.

Focal areas of discontinuation and disorganization of epidermis. Apoptotic epidermal cells were also observed in the epidermis of these aged rats of subgroup IIIa in this study. Some authors added that failure of the integrity of the intercellular cell junction leads to separation of the epithelial cells ${ }^{[24]}$.
The dermis of the aged rats of subgroup IIIa in the present study contained few disorganized collagen fibers. Several areas of collagen loss were also seen between these distorted collagen fibers. Some areas of the dermis showed focal areas of mononuclear cellular infiltration. The skin of this group also showed few faint elastic fibers in the dermis and very few hardly detected in subcutaneous tissue. Empty spaces were also observed between these fibres. These came accordance with some authors who stated that increasing age leads to reduced fibroblast activity, reduced collagen and hyaluronic acid content and more fragmented elastin fibers within the dermis ${ }^{[25]}$. Mononuclear cellular infiltration (mostly mast cells) which release collagenases include matrix metalloproteinase s (MMP) MMP-1, MMP8 and MMP-13. These MMPs attack triple helical regions of interstitial collagen types. This cleavage makes fragments approximately three-fourths and one-fourth of the size of the collagen molecules. This was suggested of wide empty spaces were seen between the distorted collagen fibers ${ }^{[26]}$.

Examination of the dermis and subcutaneous tissue of aged rats by electron microscope (subgroup IIIa) showed few inactive fibroblasts in between few disorganized collagen fibers. Nuclei of fibroblasts contained irregular nuclear membrane and abnormal chromatin distribution. Their cytoplasm lacked organelles. Few widely dispersed irregularly arranged collagen fibrils were also observed beside cells. The observed changes in the fibrobalsts of the dermis of these rats might affect their function with subsequent production of the disorganized collagen fibers. Some authors proved that older skin contains a greater proportion of fragmented collagen. They explained that fragmentation of collagen reduces the structural integrity of the extracellular matrix, producing less mechanical tension on fibroblasts and appearance of "collapsed" fibroblasts with subsequant reduction of collagen production ${ }^{[27]}$. Moreover, some authors observed progressive decrease in collagen, elastin and proteoglycans content in the dermis during aging. They also added that the matrix proteins become fragmented with little spatial structure ${ }^{[28]}$.

Immunohistochemical staining for CD34 of subcutaneous tissue of aged rats of this study revealed a faint immune reaction in the endothelium of few blood capillaries. The observed decreased vascularity might affect the function of the surrounding cells as fibroblasts with subsequent reduction in collagen and elastic fibers synthesis. Similarly, previous researchers ${ }^{[25]}$ stated that increasing age leads to decreased vascularity of the skin.

Examination of sections of aged rats of subgroup IIIb showed that the structure of the epidermis, dermis and the subcutaneous tissue was nearly similar to the control adult rats. Statistical results revealed a significant increase in the total thickness of the epidermis and dermis as well as the subcutaneous tissue of these animals as compared to that of senile rats of subgroup IIIa. It was confirmed by electron microscope examination of the dermis of these rats revealed that the fibroblasts were surrounded by regularly arranged collagen fibers. Numerous mitochondria were detected 
in their cytoplasm as well as some rough endoplasmic reticulum. Filopodia extended from the cell surface to the nearby collagen fibers. All these findings suggest the activity of the fibroblasts. This was in agreement with previous researchers who stated that when HA introduced to discrete areas within damaged skin, it flows into areas containing fragmented fibers, pushes on the existing fibers and creates a rigid scaffold that approximates younger dermis $^{[17]}$. This provides an increase in mechanical tension that stimulates fibroblasts to produce new intact collagen. It was seen that local injection of HA to these rats (subgroup IIIb) might improve the vascularity and stimulate formation of collagen and elastic fibers by these active fibroblasts.

Closely packed collagen fibers were seen in both layers of the dermis. Thin branched elastic fibers were also noticed in the subcutaneous tissue. Numerous blood vessels were also detected in the subcutaneous tissue. The observed increase in immune reaction in animals of the subgroup IIIb might occur secondary to stimulation of HA to induce proliferation of endothelial cells of blood capillaries. This was explained by Noble who stated that oligomers of HA can activate noninflammatory cells to proliferate, migrate and trigger wound healing or tissue remodeling. He added that interaction of HA with one or more receptors as CD44, receptor for hyaluronan-mediated motility (RHAMM) and toll-like-receptor-4 (TLR-4) promote endothelial cell proliferation and migration ${ }^{[29]}$.

Regarding the mechanism of action of HA, Many authors mentioned that mechanical stretching stimulates fibroblasts to produce growth factors and tissue inhibitors of matrix metalloproteinases ${ }^{[30]}$. Others authors, mentioned that fibroblasts are activated by hyaluronic acid itself. They explained that hyaluronic acid directly stimulates the surrounding cells by means of hyaluronan receptors as CD44 and CD168 which are expressed on the cell membrane of fibroblasts, causes an increase in extracellular matrix constituents such as collagen, elastin and proteoglycan,also causing fibroblast migration, proliferation $^{[20]}$ and can stimulates stem cell niches ${ }^{[16]}$. Some authors explained that as focal adhesions play an important role in sensing and transmitting signals from the extracellular environment into the interior of the cell. They able to detect contractile forces or mechanical changes in the extracellular matrix and convert them into biochemical signals. This phenomenon called mechanosensitivity,allow cells to alter their adhesion-mediated functions in response to external mechanical stimuli.Intergrins transmit these signals to the interior of the cell,where affect their migration, differentiation and growth.Focal adhesion proteins serve as a common point of entry for signals resulting from stimulation of various classes of growth factors receptors ${ }^{[31]}$.

\section{CONFLICT OF INTEREST}

There are no conflicts of interest.

\section{REFERENCES}

1. Luebberding $\mathrm{S}$ and Alexiades-Armenakas $\mathrm{M}$. Facial volume augmentation in overview of different filler options. J Drugs Dermatol 2013; 12:1339-1344.

2. Landau M and Fagien S. Science of Hyaluronic Acid Beyond Filling: Fibroblasts and Their Response to the Extracellular Matrix Plast. Reconstr. Surg 2015; 136: 188S.

3. Lin ZY, Shah V, Dhinakar A, Yildirimer L, Cui WG, Zhao X. Intradermal fillers for minimally invasive treatment of facial aging. Plast Aesthet Res 2016; 3:72-82.

4. Liew S, Scamp T, de Maio M, Halstead M, Johnston N, Silberberg M, and Rogers JD. Efficacy and Safety of a Hyaluronic Acid Filler to Correct Aesthetically Detracting or Deficient Features of the Asian Nose. A Prospective, Open-Label, LongTerm Study Aesthetic Surgery Journal 2016; 36(7) 760-772.

5. Prasetyo AD, Prager W, Rubin MG, Moretti EA, Nikolis A. Hyaluronic acid fillers with cohesive polydensified matrix for soft-tissue augmentation and rejuvenation: a literature review; Clin Cosmet Investig Dermatol 2016; 9: 257-280.

6. Jung-Bo H, Joo-Hyun K, Soyun K, So-Hyoun L, Kyung MS, Se E K, Seong SK, and Chang-Mo J. Effects of PMMA and Cross-Linked Dextran Filler for Soft Tissue Augmentation in RatsInt J Mol Sci, 2015; 16(12): 28523-28533.

7. Zimmers TA, Sheldon J, Lubarsky DA, LópezMuñoz F, Waterman L, Weisman R, Koniaris LG. Lethal Injection for Execution: Chemical Asphyxiation? PLoS Med 2007; 4(4): e156.

8. Suvarna SK, Floyd AD and Bancroft JD. Bancroft's Theory and Practice of Histological Techniques, $7^{\text {th }}$ ed. Churchill Livingstone Philadelphia USA 2013; pp. 151, 203, 500.

9. Crookham J and Dapson R. Hazardous Chemicals in the Histopathlogy Laboratory 1991; 2nd ED, Anatech.

10. Ramani, P, Bradley, NJ, Fletcher, CDM. QBend10, a new monoclonal antibody to endothelium: assessment of its diagnostic utility in paraffin sections. Histopathology 1990; 17:237-242.

11. Plastic Surgery Procedural Statistics: http://www. plasticsurgery. org/Documents/news-resources/ statistics/2012-Plastic-Surgery-Statistics/plasticsurgery-trends-quick-facts.pdf. Accessed (2012). 
12. McKnight A, Momoh AO, Bullocks JM. Variations of structural components. Specific intercultural differences in facial morphology, skin type, and structures. Semin Plast Surg 2009; 23(3):163-167.

13. Rzany B, Hilton S, Prager W, Hartmann V, Brandl G, Fischer TC, Gekeler O, Glöckner S, Gramlich G, Hartmann M, Lederman K, Luckner-Neugebauer J, Pavicic T, Stangl S, Walker T, Zenker S, Wolters $\mathrm{M}$. Expert guideline on the use of porcine collagen in aesthetic medicine. J Dtsch Dermatol Ges 2010; $8(3): 210-217$.

14. Flynn TC, Sarazin D, Bezzola A, Terrani C, Micheels P. Comparative histology of intradermal implantation of mono- and biphasic hyaluronic acid fillers. Dermatol Surg 2011; 37(5):637-643.

15. Tezel A and Fredrickson GH. The science of hyaluronic acid dermal fillers. J Cosmet Laser Ther. 2008; 10: 35-42.

16. Solis MA1, Chen YH, Wong TY, Bittencourt VZ, Lin YC, Huang LL. Hyaluronan regulates cell behavior: a potential niche matrix for stem cells. Biochem Res Int. Volume 2012, Article ID 346972 , 11 pages. 2012; 2012346972.

17. Wang F, Garza LA, Kang S, Varani J, Orringer JS, Fisher GJ, Voorhees JJ. In Vivo Stimulation of De Novo Collagen Production Caused by Crosslinked Hyaluronic Acid Dermal Filler Injections in Photodamaged Human Skin. Arch Dermatol 2007; 143: $155-163$.

18. PandiarDandShameenaPM.Immunohistochemical expression of CD34 and basic fibroblast growth factor (bFGF) in oral submucous fibrosis Journal of Oral and Maxillofacial Pathology 2014; 18 (2): 155-161.

19. Shukla S, Nair R, Rolle MW, Braun KR, Chan CK, Johnson PY, Wight TN, McDevitt TC.Synthesis and organization of hyaluronan and versican by embryonic stem cells undergoing embryoid body differentiation. Journal of Histochemistry and Cytochemistry. 2010; 58(4):345-358.

20. Mochizuki M, Aoi N, Gonda K, Hirabayashi S, Komuro Y. Evaluation of the In Vivo Kinetics and Biostimulatory Effects of Subcutaneously Injected Hyaluronic Acid Filler; Plast Reconstr Surg 2018; 142(1):112-121.

21. Paliwal S, Fagien S, Sun $X$, Holt $T$, Kim $T$, Hee C K., Van Epps D, Messina DJ. Skin
Extracellular Matrix Stimulation following Injection of a Hyaluronic Acid-Based Dermal Filler in a Rat Model. Plast. Reconstr. Surg 2014; 134(6): 1224-1233.

22. Wang YZ, Cao ML, Liu YW, He YQ, Yang CX, Gao F. CD44 mediates oligosaccharides of hyaluronaninduced proliferation, tube formation and signal transduction in endothelial cells. Experimental Biology and Medicine. 2011; 236(1):84-90.

23. Neerken S, Lucassen GW, Bisschop MA, Lenderink E and Nuijs TA. Characterization of agerelated effects in human skin: A comparative study that applies confocal laser scanning microscopy and optical coherence tomography. J Biomed Opt. 2004; 2 : 274-81.

24. Panth A and Ramam M. Epidermal reaction patterns. Indian J Dermatopathol Diagn Dermatol 2015; 2:1-7.

25. Stevenson $\mathrm{S}$ and Thornton J. Effect of estrogens on skin aging and the potential role of SERMs, Clin Interv Aging 2007; 2(3): 283-297.

26. Yasunori Okada. In Kelley and Firestein's Textbook of Rheumatology (Tenth Edition), 2017.

27. Varani J, Perone P, Fligiel SE, Fisher GJ, Voorhees JJ. Inhibition of type I procollagen production in photodamage: correlation between presence of high molecular weight collagen fragments and reduced procollagen synthesis. J Invest Dermatol 2002; 119: 122-129.

28. Lynch B, Bonod-Bidaud C, Ducourthial G, Affagard JS, Bancelin S, Psilodimitrakopoulos S, Ruggiero F, Allain JM, Schanne-Klein MC. How aging impacts skin biomechanics: a multiscale study in mice. Sci Rep 2017; 7(1):13150-13154.

29. Noble PW. Hyaluronan and its catabolic products in tissue injury and repair. Matrix Biol 2002; $21: 25-29$

30. Kessler D, Dethlefsen S, Haase I, Plomann M, Hirche F, Krieg T, Eckes B. Fibroblasts in mechanically stressed collagen lattices assume a "synthetic" phenotype. J Biol Chem. 2001; 276(39):36575-36585.

31. Ross MH and Pawlina W."Histology: a text and atlas, with correlated cell and molecular biology". In: chapter 5: Epithelial Tissue. Seventh edition. Lippincott Williams and Wilkins Publishing. Baltimore, Philadelphia - USA,; 2016, p.105-148. 


\section{الملخص العربى}

\section{دراسة هستولوجية على تأثير حقن الهيالورونيك (حشو جلدي) على جلد البالغين والكبار من الجرذ الأبيض التوني}

ماريان جمال مجدي عزيز أرمانيوس، الهام جمال الدين، سهير كمال أحمد، محمد عبدالرحمن أحمد مكاوي قسم الهستولوجيا وبيولوجيا الخلية ـ كلية الطب- جامعة عين شمس- مصر

المقدمة: لقد أصبحت حشوات الجلد عن طريق الحقن الاكثرشعبية لتحسين عيوب كفاف الجلد مثل التجاعيد و الخطوط

$$
\text { وندبات حب الثباب المنخفضة. }
$$

الهـف من البحث: يهدف هذا العمل لدر اسة التغير ات الجلدية المختلفة الناجمة عن حقن حشو الجلد في الجرذان البيضاء. مواد وطرق البحث: تم استخدام خمسة وأربعين أنتى من الجرذان البيضاء. كما تم تقسيم الحيو انات إلى ثلاث مجمو عات: المجمو عة الأولى (الضابطة): شملت عشرين جرذا بالغاً. المجموعة الثانية: وشملت خمسة عشر من الجرذان البالغة، تلقو ا حقنة من حمض الهيالورونيك بجر عة 0.1 مل. تم تقسيم هذه الحيو انات إلى ثنلاث مجموعات فرعية حسب وقت التضحية بهم، كل منها خمسة جرذان: المجموعة الفرعية 2أ: بعد 7 أيام. المجموعة الفرعية باب: بعد .ج يومًا. مجموعة الفرعية بت: بعد .9 يومًا. المجموعة الثالثة: وشملت عشرة جرذان مسنة، تم تقسيمها إلى مجموعتين فر عيتين، كل منها خمس جرذان: المجمو عة الفرعية 3أ: المجمو عةالضابطة للجرذان المسنة, المجمو عة الفرعية 3ب:

أعطيت الجرذان حقنة من حمض الهيالورونيك وتم التضحية بها بعد ·ـ بورًا. النتائج: كثفت البشرة الرقيقة للحيوانات المحقونة بحمض الهيالورونيك عن زيادة ذي دلالة أحصائية (>0.05) في كل من سماكة النسيج تحت الجلد وفي ألياف و الكو لاجين و الألياف المرنة ، و أيضا في الخلايا البطانية الإيجابية للسي دي 乏ץ مقارنة بالمجموعة الضابطة والمجموعة المسنة. الخلايا الليفية النشطة في موقع الحقن تظهر أنوية متناظرة. و أحتوي السيتوبلازم لديهر على شبكة إندوبلازمية داخلية متطورة بشكل جيد, و العديد من الميتوكوندريا ،و العديد من

$$
\text { الحويصلات ، و والمريكز. }
$$

الخلاصة: يعمل حشو حمض الهيالورونيك علي تحفيز الخلايا الليفية لتصنيع ألياف الكولجين و الألياف المرنة في النسيج تحت الجلد و أيضا علي زيادة الأوعية الدموية.و هذا بدوره يعمل علي حماية جلد البشرة من مظاهر الثيخوخة لدى البالغين، ويلعب دوراً في تحسين عيوب البشرة في الجرذان المسنة. 